\title{
لحثث بعنوان
}

المواطنة الرقمية وعلاقتها بالوعي الفكري لاى طلاب كلية الخدمة الاجتماعية

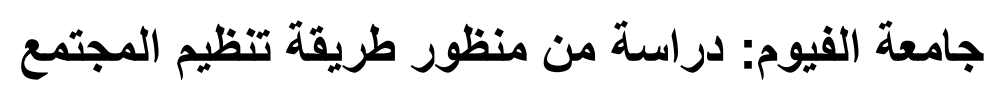

\section{إعداد}

\author{
دا مروة جمعة عبد الغني بسيوني \\ مدرس بقسم طرق الخدمة آلاجتماعيّة \\ كلية الخدمة الاجتماعية الخاعيكاع \\ جامعة الفيوم الإنماع
}

$5 r \cdot r)$ 
مجلة كلية الخدمة الاجتماعية للار اسات و البحوث الاجتماعية - جامعة الفيوك 
المواطنة الرقمية وعلاقتها بالوعي الفكري لاى طلاب كلية الخدمة الاجتماعية جامعة الفيوم:

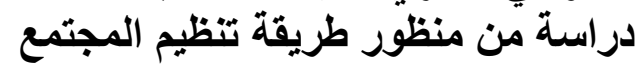

ملخص الدراسة: تهدف الدراسة الحالية إلى الكثف عن طبيعة العلاقة بين المواطنة الرقمية والوعي الفكري لدى

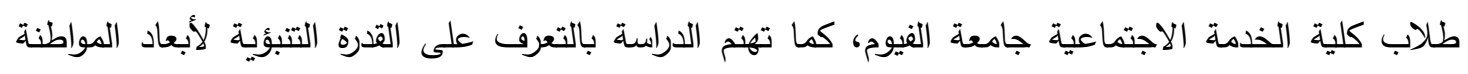

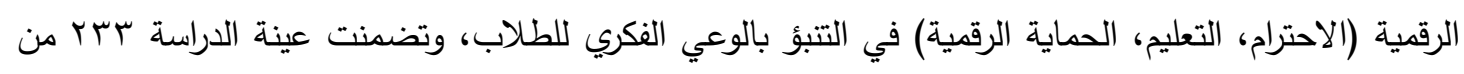

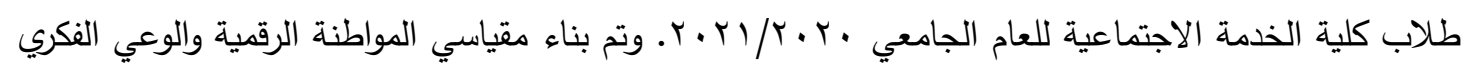
(إعداد الباحثة)، وتم التحقق من الخصائص السيكومترية لمقياسي الدراسة، وقد أظهرت النتائج أن مقياس

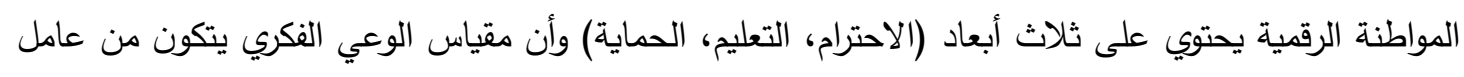

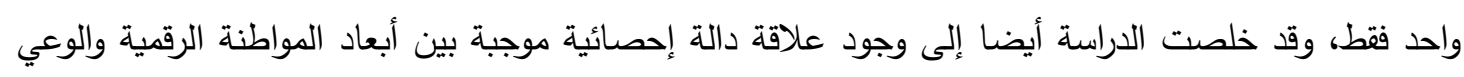
الفكري، كما أسفرت النتائج عن وجود فروق دالة إحصائية بين الذكور والإناث في محور التعليم تعزي لصالح

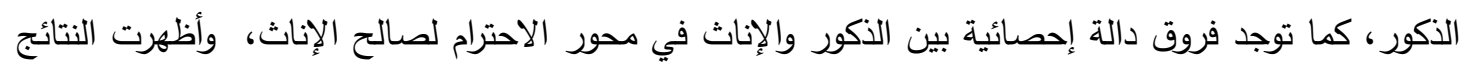
أنه لا توجد فروق دالة إحصائية في الوعي الفكري تعزي للنوع، وأثارت النتائج إلى أن محوري الاحترام والحماية

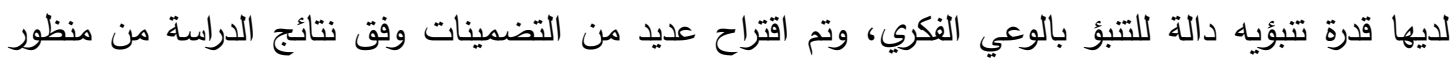
طريقة تنظيم المجتمع.

الكلمات المفتاحية: الدواطنة الرقمية، الوعي الفكري، طلاب الجامعة، تنظيم الدجتهع. 


\title{
Relationship between Digital Citizenship and Intellectual Consciousness among Students of the Faculty of Social Work, Fayoum University: A study from the perspective of the Community Organization Method
}

\author{
Marwa Gomaa Abdelghani Bassiouni \\ Department of Methods of Social Work, Faculty of Social Work, Fayoum University, Fayoum, Egypt
}

\begin{abstract}
The current study also sought to identify the nature of the relationship between digital citizenship and intellectual consciousness among students of the Faculty of Social Service University of Fayoum. In addition, the study focuses on identifying the predictive ability of digital citizenship factors (respect, education, and digital protection) in predicting students' intellectual consciousness. The study sample included 233 students from the faculty of social work for the academic year 2020/2021. The measures of digital citizenship and intellectual consciousness were developed (researcher preparation). The two measures' psychometric properties were investigated. The results showed that digital citizenship consisted of three factors (respect, education, and protection) and the measure of intellectual consciousness consisted of only one factor. The findings revealed that there was a significant positive correlation between the factors of digital citizenship and intellectual consciousness. Furthermore, the results also revealed that there was a significant difference between males and females in the education factor in favor of males. In addition, there was a significant difference between males and females in the respect factor in favor of females. The results also revealed that there were no statistically significant differences in intellectual consciousness attributed to the gender variable. The results also indicated that respect and protection factors have a predictive ability to predict intellectual consciousness. Several implications were suggested according to the results of the study from the perspective of the method of community organization.
\end{abstract}

Keywords. Digital citizenship, intellectual consciousness, university students, community organization. 


\section{أولاًا- مدخل إلى مشكلة الاراسة:}

تحظى المجتمعات المتطورة في ظل العصر الرقمي على استخدام الأفراد تكنولوجيا الاتصالات والمعلومات

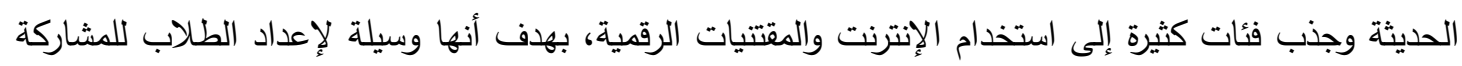

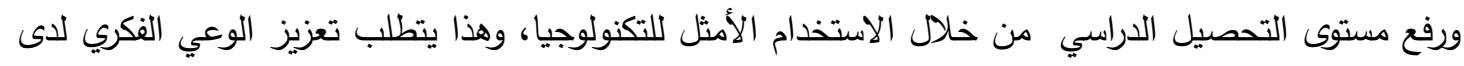

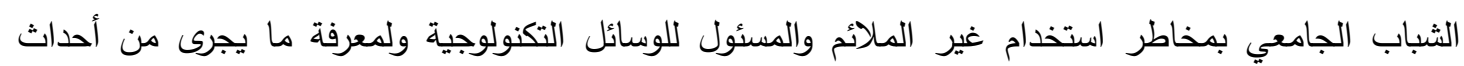

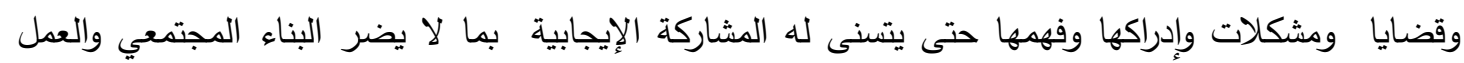
على تدعيم منظومة القيم وقواعد السلوك الرشيد في المجتمع.

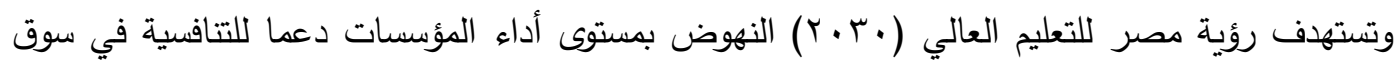

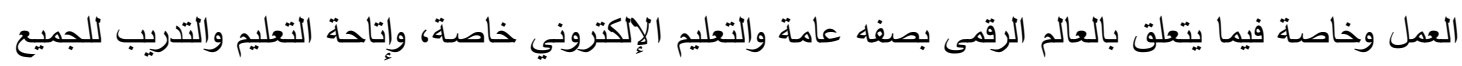

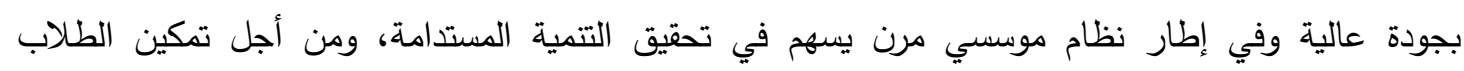

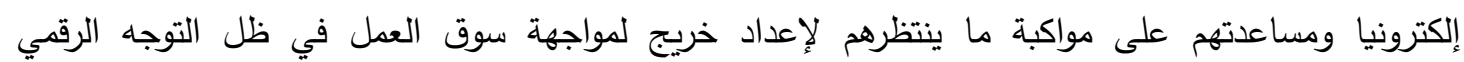
للاقتصاد.

كما يشهد التعليم الإلكتروني في الفترة الحالية اهتمامًا متزايدًا من قبل القائمين على العملية التعليمية واستخدام التقنيات بمختلف أثكالها، والقدرة على استخدام آليات الاتصال الحديثة والمكتبات رقمية، بهدف وصول المعلومة للمتلقي في أقصر وقت ممكن وبأقل جهد، حيث يقدم التعلم الإكتروني في القرن العشرين

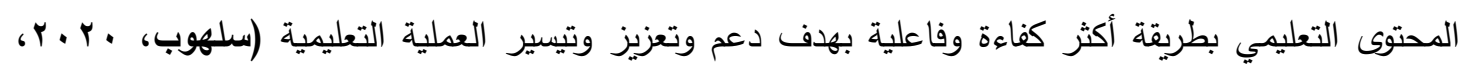

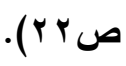

وتعد مرحلة الثباب الجامعي الثروة الحقيقية للمجتمعات، كونهم يمثلون الثريحة الأكبر في المجتمع،

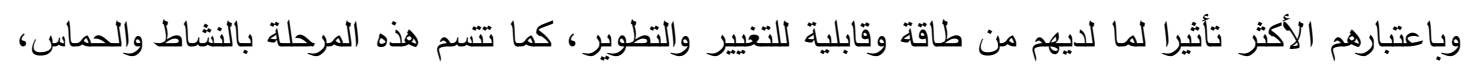
والرغبة في التغيير والاكتشاف ويتطلب ذلك من أصحاب القرار حماية هذه الفئة ورعايتها من خطر قلتة التئ الوعي

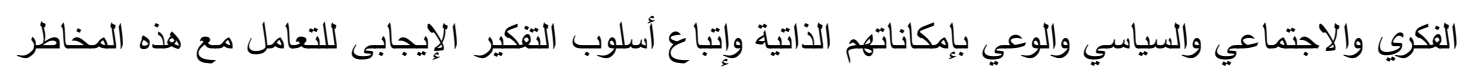

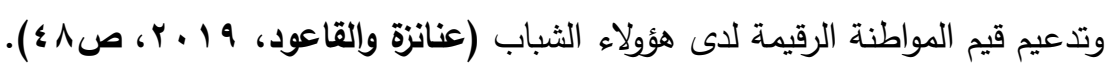

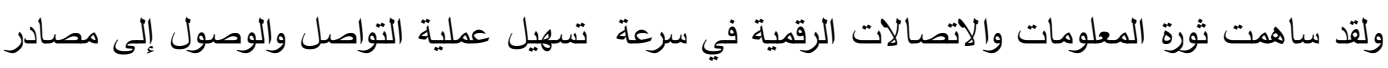
المعلومات، والنتائج الإيجابية المترتبة على هذه الثورة على الفرد والمجتمع إذا تم استثمار وسائل الاتصال

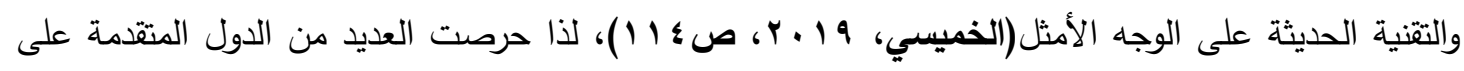
أن تدرس طلابها مواضيع خاصة بالمواطنة الرقمية إيمانا بأهمية فلسفة التربية التي تعد أولى المصادر التي

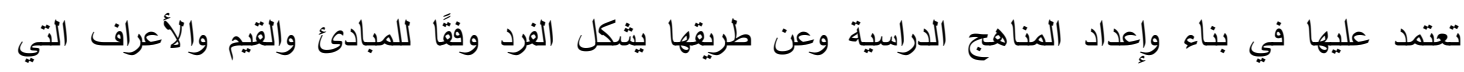

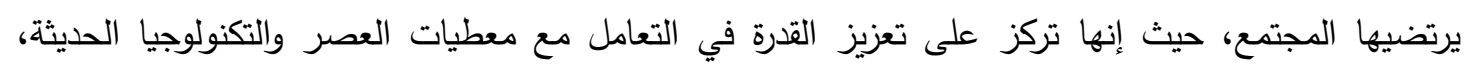

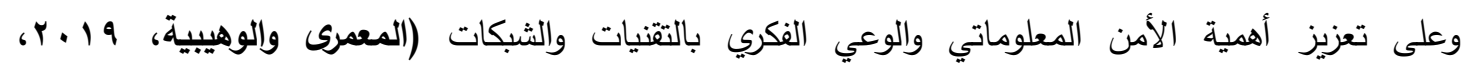

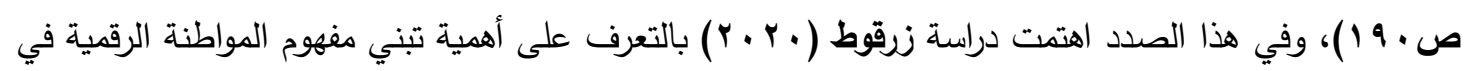

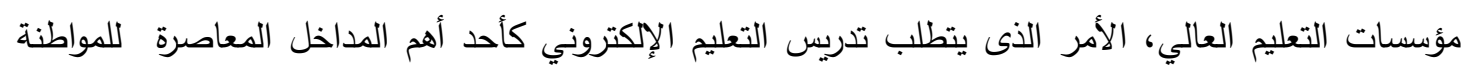

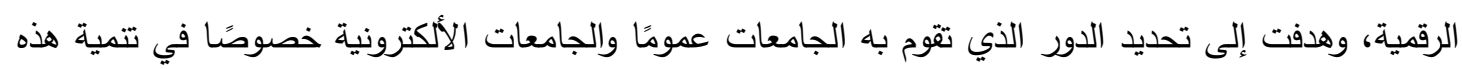

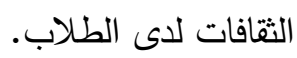


واهتمت العديد من الدراسات السابقة بالكثف عن مستويات الوعي بالمواطنة الرقمية لاى طلاب الجامعة وعلاقتها ببعض المتغيرات الأخرى منها دراسة الراشد(9 (19) التي اهتمت بالكشف عن مستوى المواطنة الرقمية لدى طلبة البكالوريوس في الجامعات الحكومية، واعداد تصور مقترح لتطويرها، واعتمدت الدراسة على المنهج

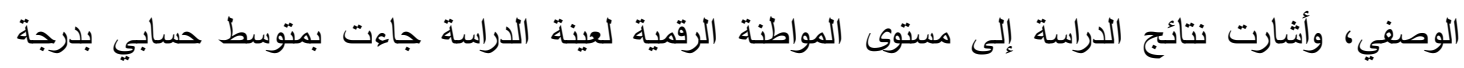
مرتفعة، وعدم وجود فروق ذات دلالة إحصائية عند مستوى بين متوسطات استجابات أفراد العينة تبعًا لمتغيرات الجنس والكلية والسنة الدراسية.

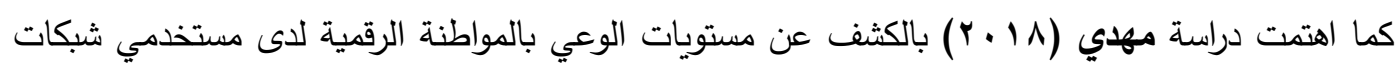
التواصل الاجتماعي من طلبة جامعة الأقصى وعلاقته ببعض المتغيرات (الثبكة المستخدمة، المعرفة، والمهارة

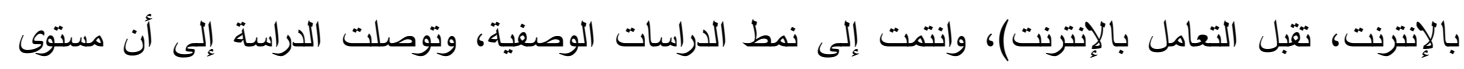
الوعي بالمواطنة الرقمية بشكل عام وصل إلى نسبة فوق المتوسط.

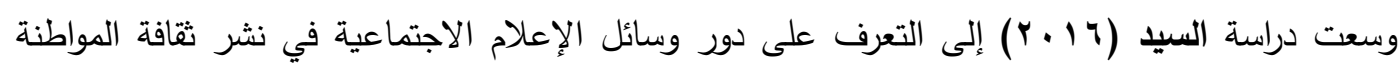

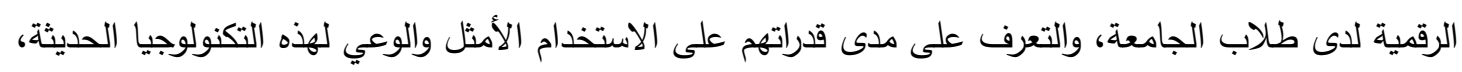

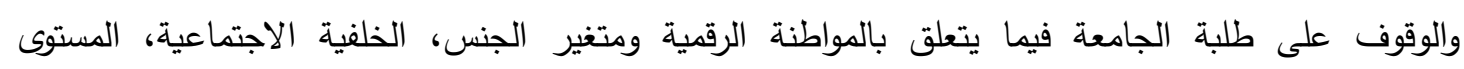

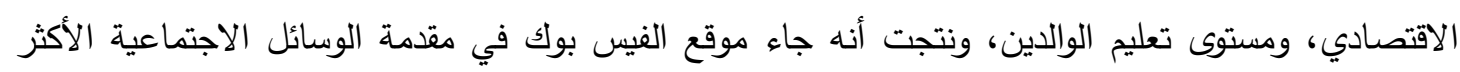

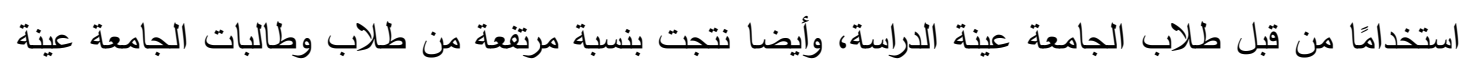

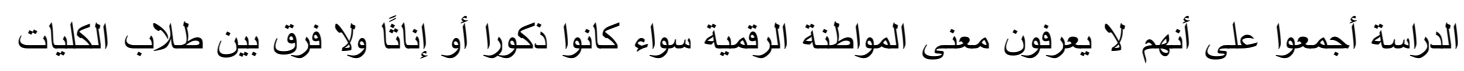
العلمية والنظرية.

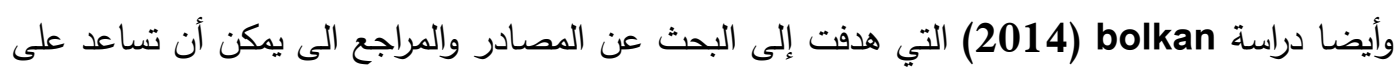
تعليم المواطنة الرقمية لطلبة المدارس، واستندت الدراسة على المنهج الوصفي، وتوصلت الدراسة إلى قائمة

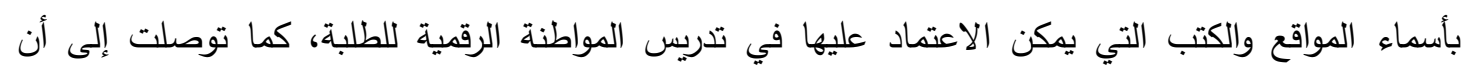

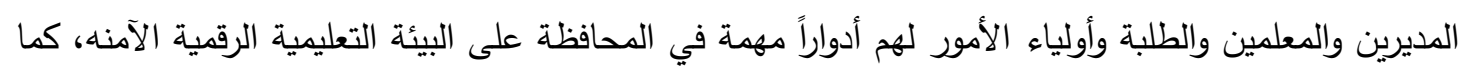

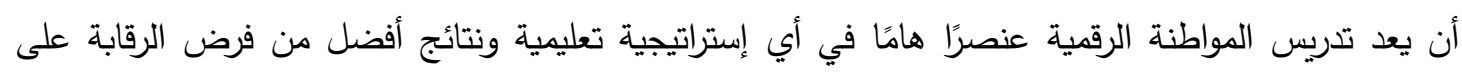

وتتقسم أبعاد المواطنة الرقمية إلى عدة أشكال لتعليم وتوضيح المواطنة الرقمية إلى ثلاث فئات، كل فئة

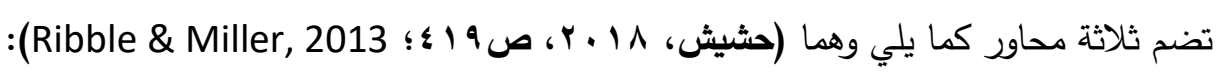

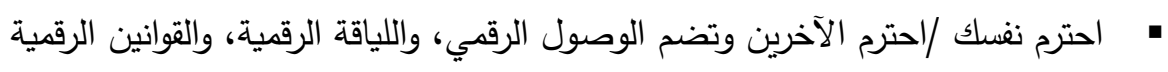

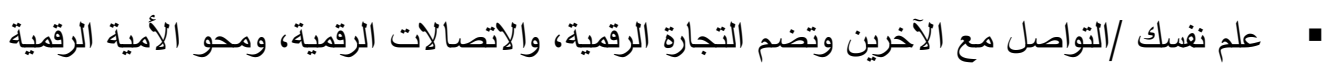

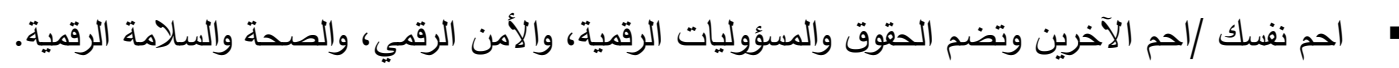

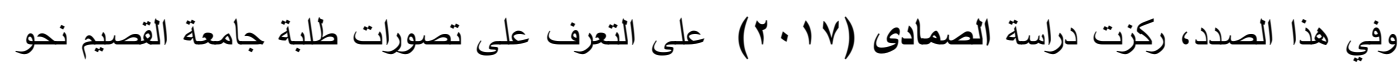

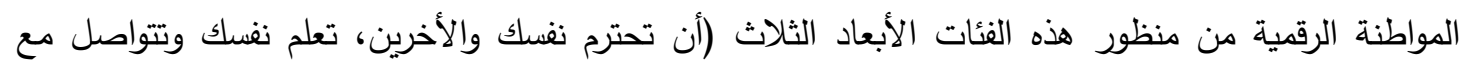

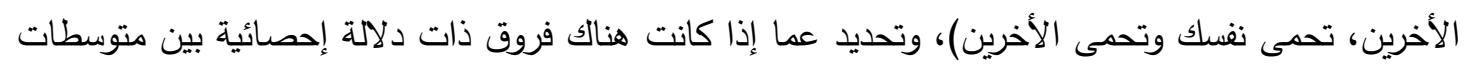

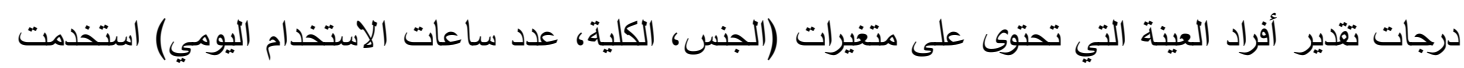

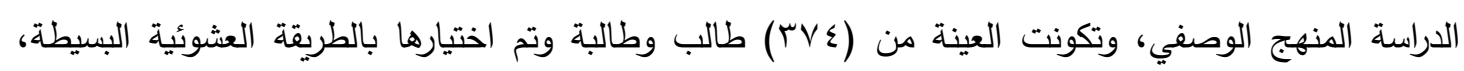

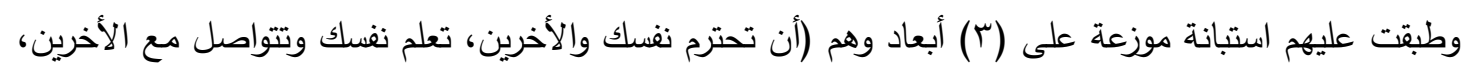

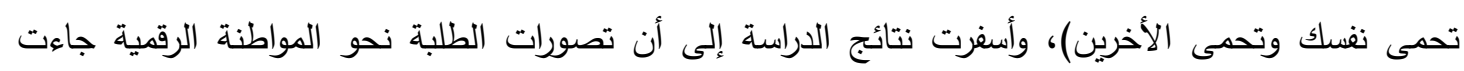


بدرجة متوسطة، كما أوصت الدراسة بضرورة توفير الوصول الرقمي للمجتمع بلا استثناء داخل المؤسسات التعليمية. وعلي الرغم من الآثار الإيجابية للبيئات الرقمية، توجد أثار سلبية واضحة على الفرد من أهمها التمرد على

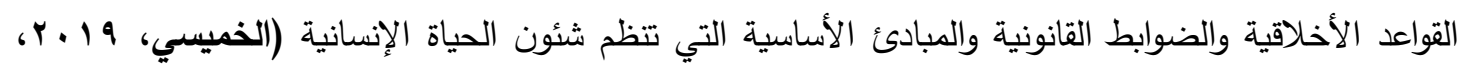

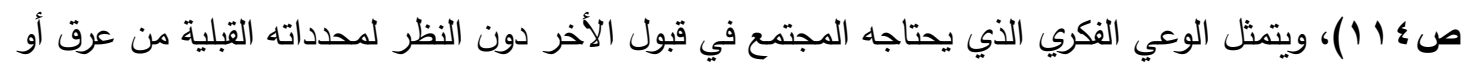

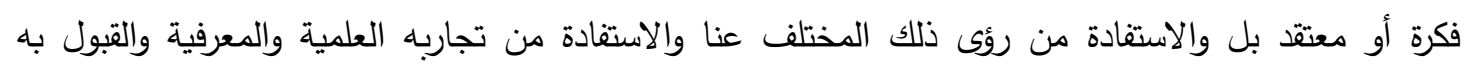

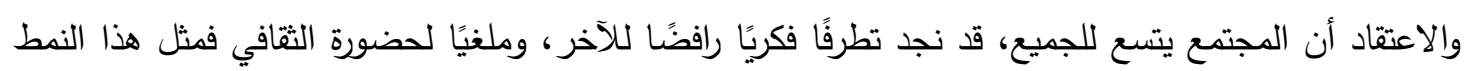

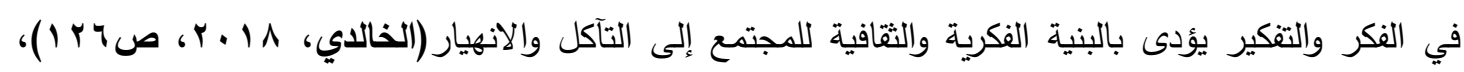

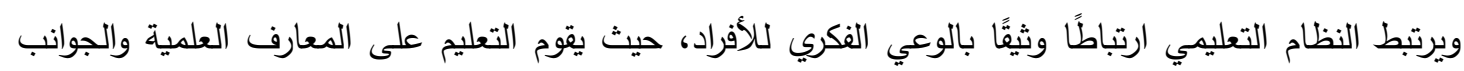

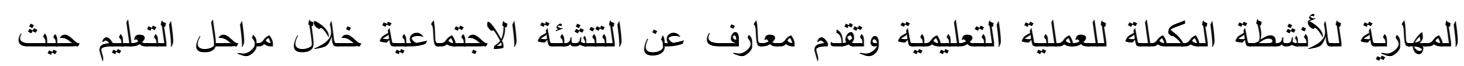

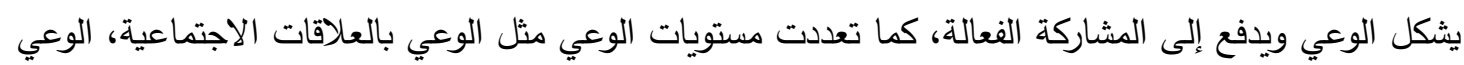
بالتغير الاجتماعي المقصود وكذلك الوعي بالبيئة المحيطة والوعي بضرورة وجود أيديولوجية وثقافة متغيرة

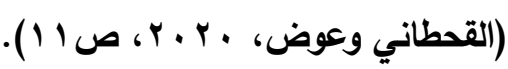

ويتأثر تكوين الوعي الفكري لاى أفراد المجتمع بمجموعة من العوامل من أهمها: التتشئة الاجتماعية،

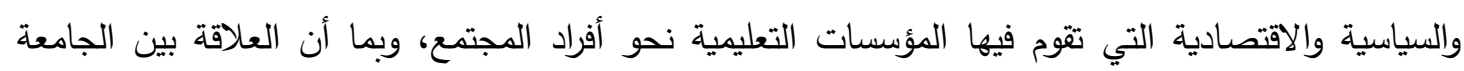
والمجتمع علاقة وثيقة فكل تغير وتطور يحدث في المجتمع ينشأ عنه تغير وتطور في التربية والتعليم(محافظة،

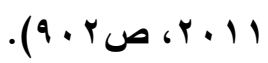
وفي هذا الصدد، كثفت عليمات (9 (19) عن دور مواقع التواصل الاجتماعي في تحقيق الوعي الفكري

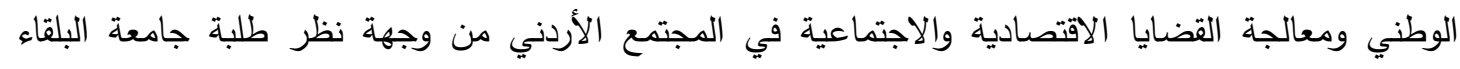

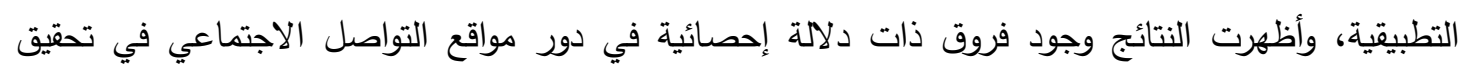

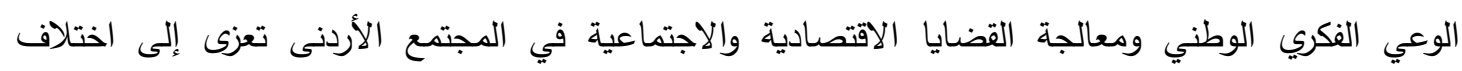

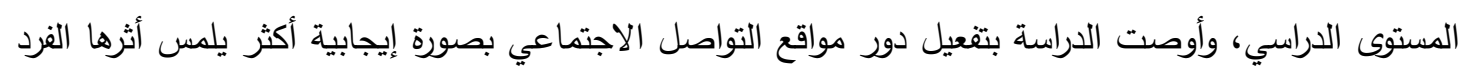
والمجتمع أولاً.

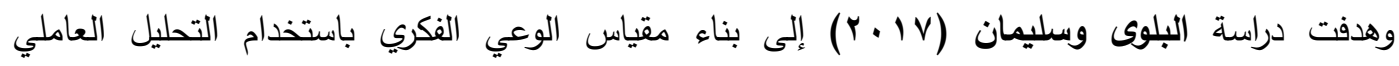

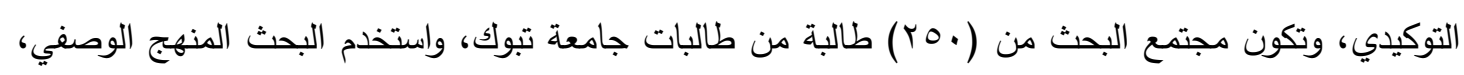

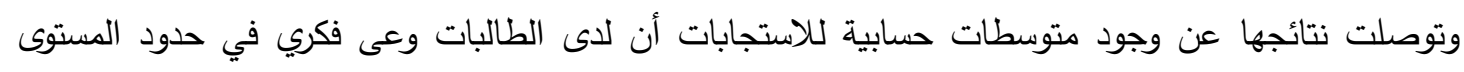

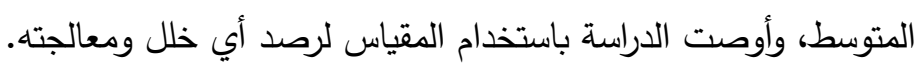

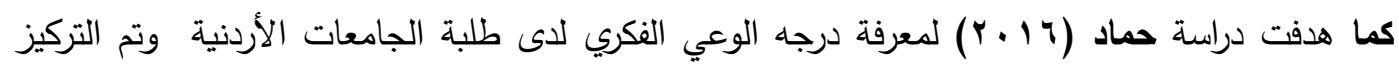

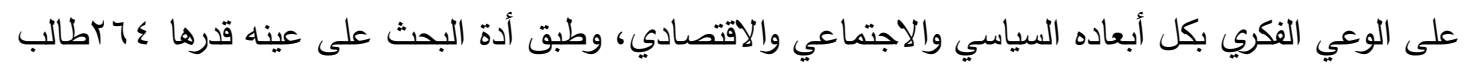

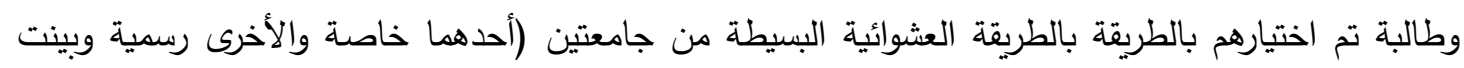
نتائج الدراسة عن وجود فروق ذات دلالة إحصائية للتفاعل بين الجنسية ونوع الجامعة لطالح الطلبة غير بالئ الأردنيين عن الطلبة الأردنيين. كما هدفت دراسة Choochom et al. (2010) إلى استكثاف وتطوير الوعي الفكري، وأظهرت النتائج أن العوامل النفسية والاجتماعية مثل التنشئة الاجتماعية والعاطفية المعرفية من الآباء والمعلمين والأصدقاء 
بالإضافة إلى ضبط النفس يمكن أن تتتبأ الوعي الفكري للطلاب والذي بدوره كان له تأثير على السلوك الاجتماعي الإيجابي للطلاب وحل المشكلات ونوعية الحياة.

وأخيرا، دراسة (2002) Prasolova-Førland التي هدفت إلى قياس الوعي الاجتماعي في الجامعات،

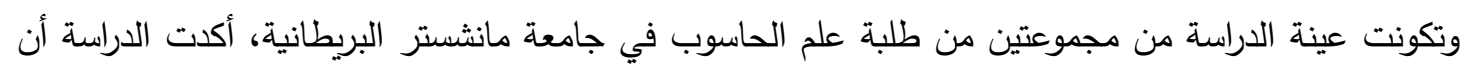

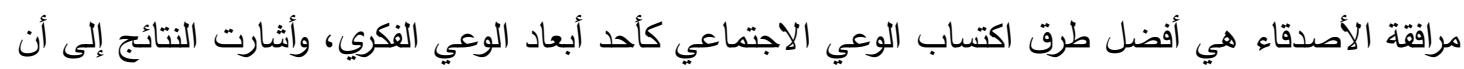

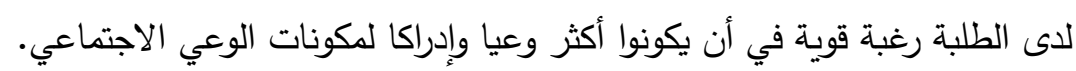

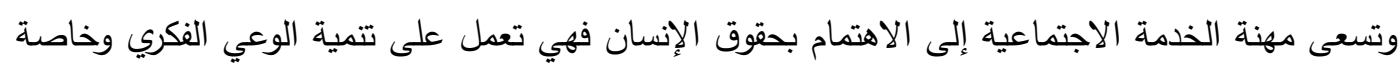

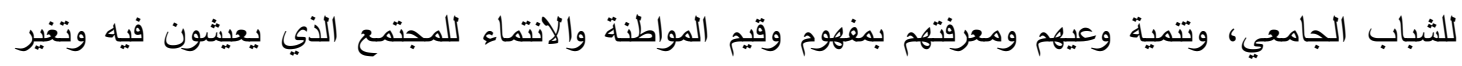

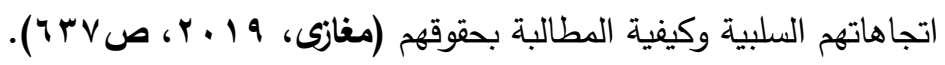

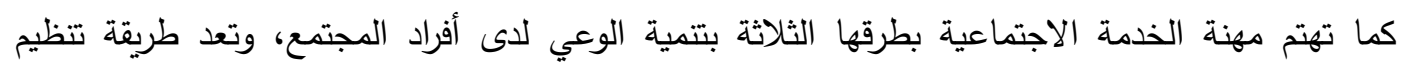

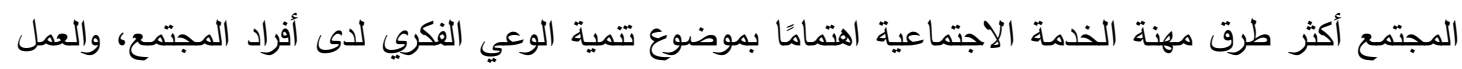

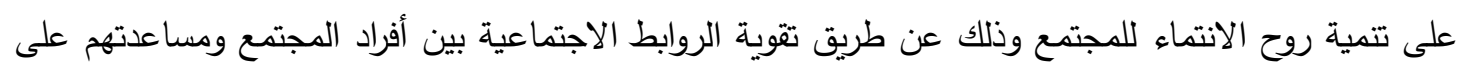

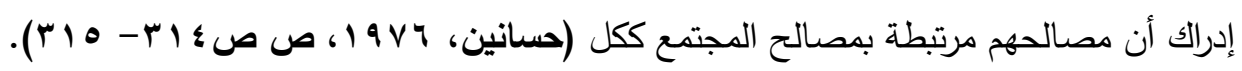

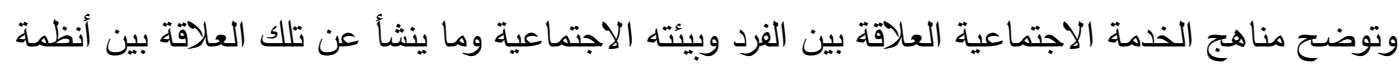

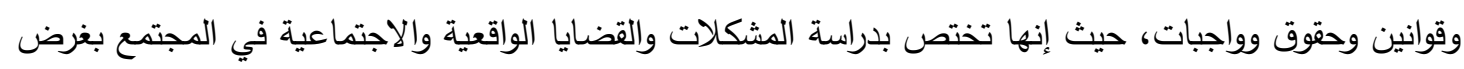

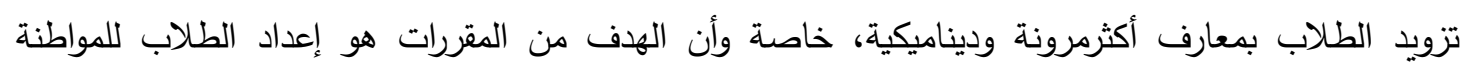

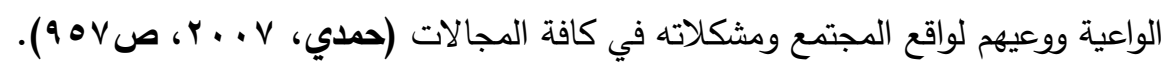

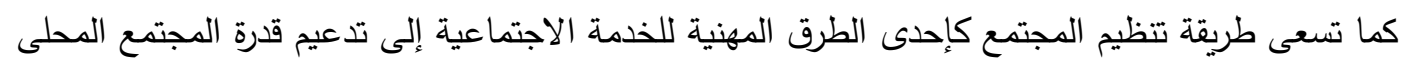
على تعبئة طاقات وجهود الأفراد من خلال تتمية قدراتهم على التفكير والإبداع والتحليل وتحديد الموارد لمواجهة

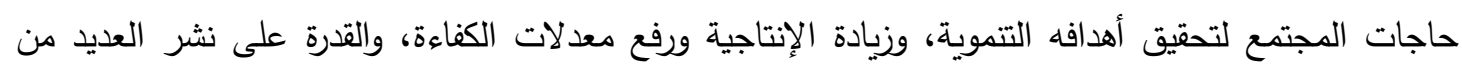

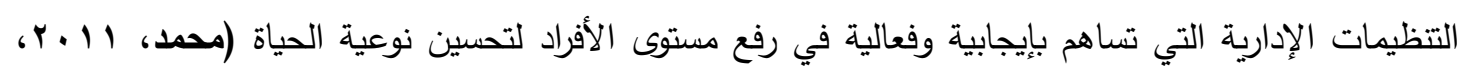
ص ص (1) (1)

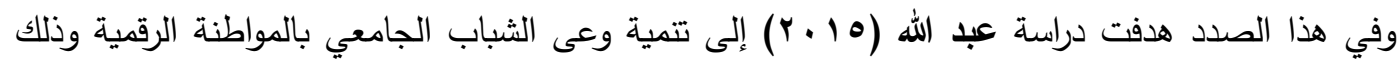

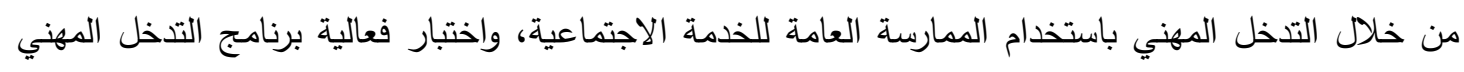
باستخدام الممارسة العامة للخدمة الاجتماعية وتنمية وعى الثباب الجامعي بالمواطنة الرقمية، وأسفرت الدراسة بأنة

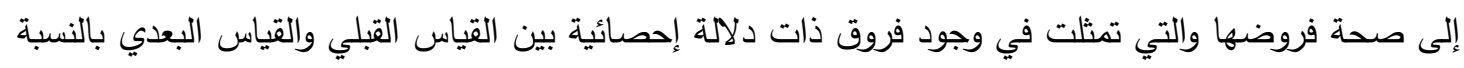
لمقياس المواطنة الرقمية لكلا من" الاحترام الرقمي، التعليم الرقمي، الحماية الرقمية.

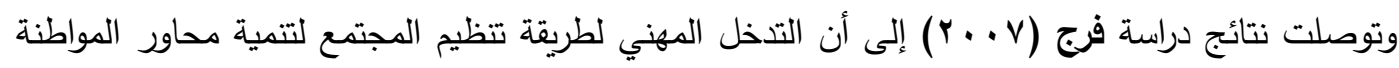

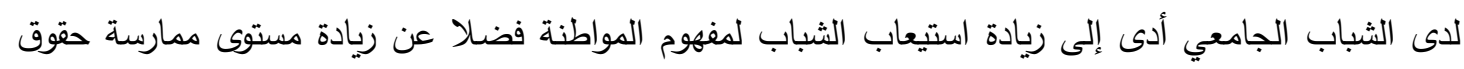

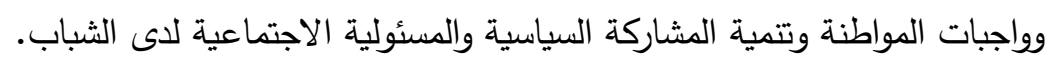
موقف الدراسة الحالية من الدراسات السابقة: 1 أكدت معظم الدراسات السابقة على علاقة طريقة تتظيم المجتمع بتدعيم وتتمية أبعاد المواطنة الرقمية من خلال قيام المنظم الاجتماعي بأداء أدواره المختلفة، تطوير البنية التحتية، وتدعيم القيم وتعزيز المهارات.

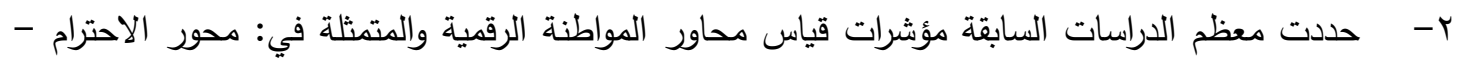

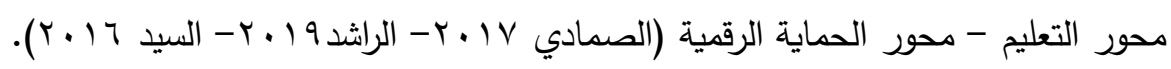


r- أجمعت الدراسات السابقة على ضرورة الاعتماد على مداخل تدريسية غير تقليدية في تتمية الوعي الفكري

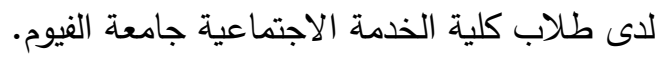
ع - تتفق الدراسة الحالية عن الدراسات السابقة في التأكيد على أهمية تعزيز الوعي الفكري لاعى طلاب كلية

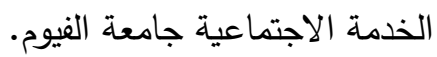

وقد استفادت الدراسة الحالية من الاراسات السابقة من خلال المساهمة في: صياغة مشكلة الدراسة

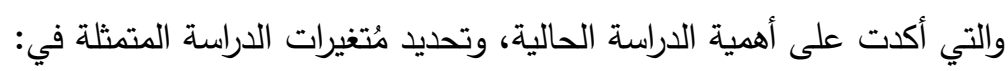
1- أبعاد المواطنة الرقمية (الاحترام - التعليم - الحماية الرقمية).

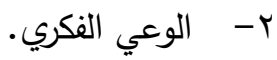

وتختلف الدراسة الحالية عن الدراسات السابقة في:

1- اعتبار المواطنة الرقمية تسهم بدورها في تعزيز الوعي الفكري لدى طلاب كلية الخدمة الاجتماعية جامعة

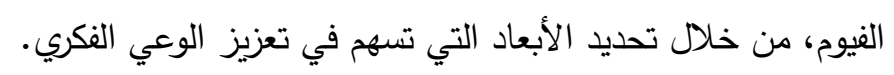

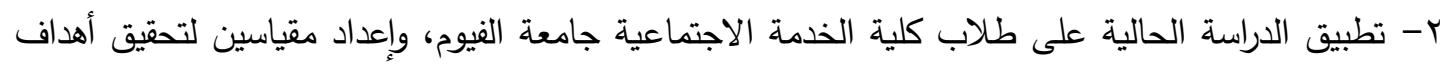
الدراسة.

ومن خلال ما سبق نستتج أن: طريقة تتظيم المجتمع تهدف إلى تدعيم أبعاد المواطنة الرقمية، كما

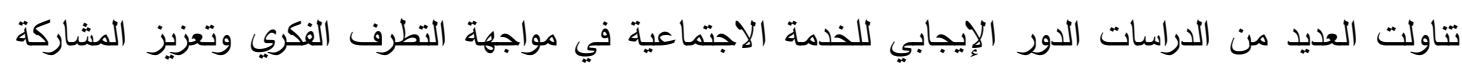

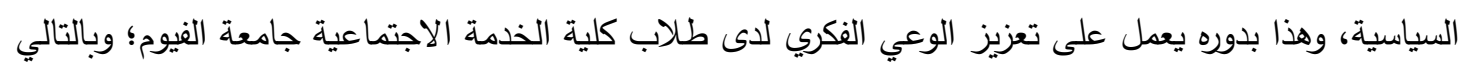

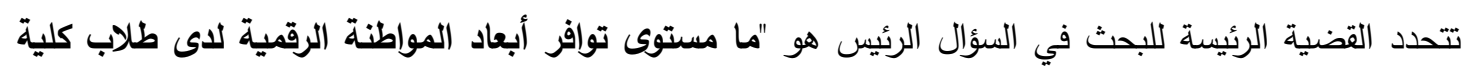

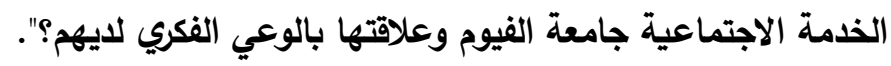

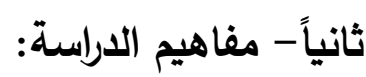
1 - مفهوم المواطنة الرقمية: أ- وتعرف المواطنة الرقمية بأنها: مجموعه المعايير والمهارات وقواعد السلوك التي يحتاج إليها الفرد في التعامل مع الوسائل التكنولوجية لكي يحترم نفسه ويحترم الآخرين، ويتعلم ويتواصل معهم ويحمي نفسه

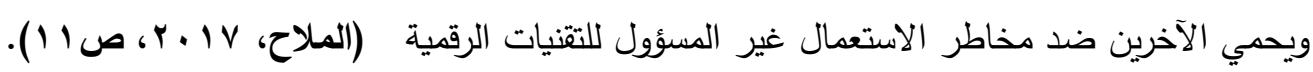

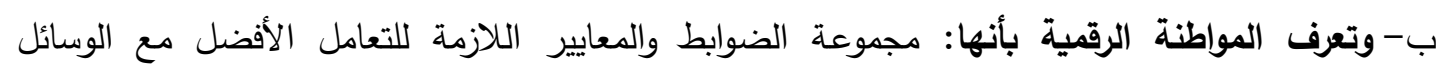

التكنولوجيا (Dotter, Hedges, \& Parker, 2016, p58).

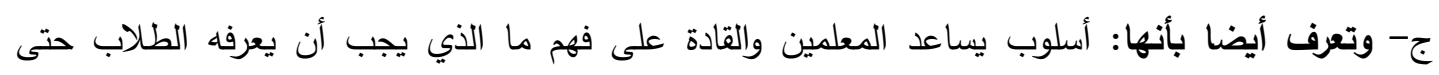

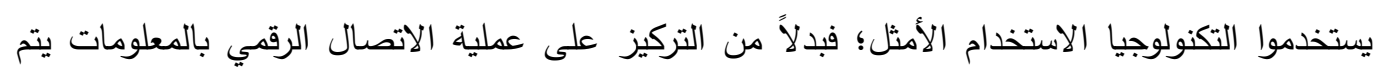

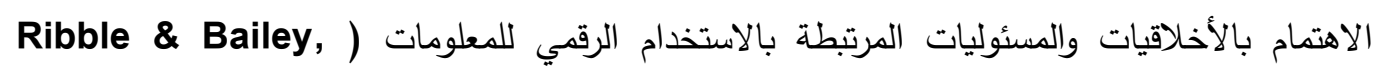
.(2007, pp.41-42 د- تعريف المواطنة الرقمية في البحث الحالي: يمكن تعريف المواطنة الرقمية إجرائيًا بأنها "مجموعة المعايير والقواعد التي تساعد في إعداد الطلاب للتعامل مع التكنولوجيا من خلال تدريبه على التقنيات الرقمية والالتزام بضوابط السلوك المقبول عند استخدام

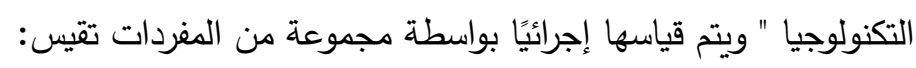


- محور الاحترام (احترم نفسك واحترم الآخرين)، والذي يمكن تعريف إجرائيًا بأنه الدرجة الكلية التي يحصل

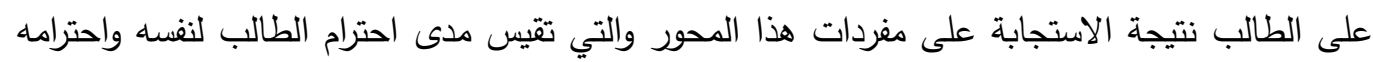
لملآخرين داخل البيئات الرقمية. محور التعليم (علم نفسك وتواصل مع الآخرين)، والذي يمكن تعريف إجرائيًا بأنه الدرجة الكلية التي يحصل عليها الطالب نتيجة الاستجابة على مفردات هذا المحور. محور الحماية الرقمية (احم نفكك واحم الآخرين)، والذي يمكن تعريف إجرائيًا بأنه الدرجة الكلية التي يحصل عليها الطالب نتيجة الاستجابة على مفردات هذا المحور والتي تقيس قدرته على حماية نفسه والآخرين عبر البيئات الرقمية.

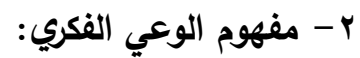
أ- الوعي يعنى في اللغة: المعرفة أو الإدراك أو الاحتواء، فوعي الثيء أئ جمعه وحواة ووعى الحديث أي

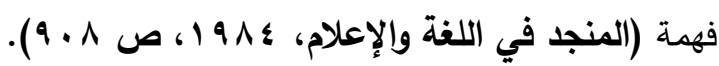
ب- فالوعي هو: الفهح وسلامة الإدراك والحفظ والتقدير، وهو إدراك الفرد لنفسه ولوظائفه وما يحيط باه، ومـع

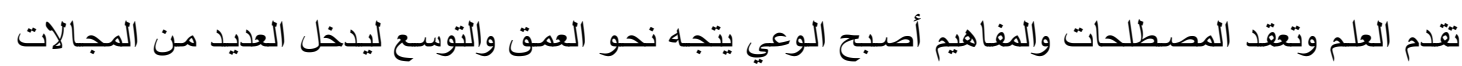

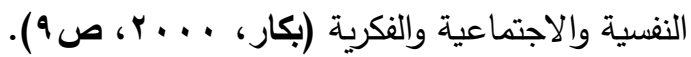
ج- الوعي هو: قدرة الإنسان على استيعاب الحقائق والأحداث من حوله، وهو يندرج في قائمة المعايير

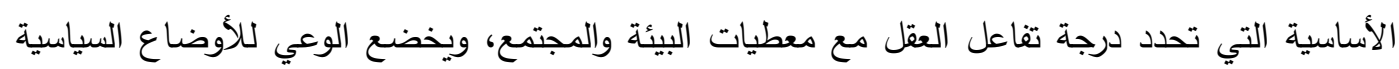

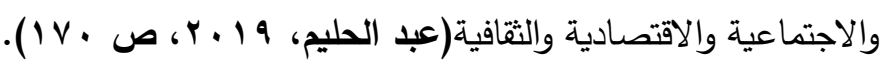

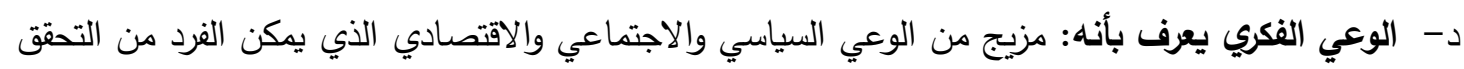

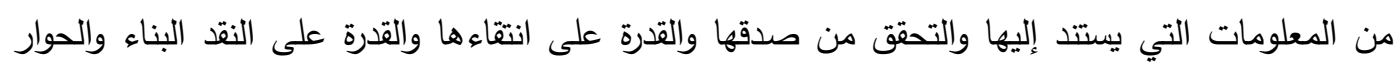

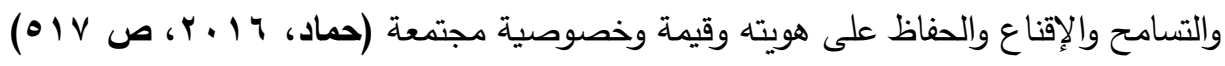

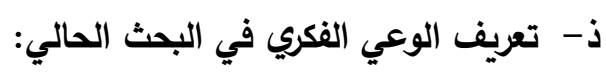
- - تتبنى الباحثة بأن الوعي الفكري عبارة عن "محصلة الأفكار والمعارف وادراك المشكلات الاجتماعية التي تميز الثباب الجامعي" ويتم قياس الوعي الفكري بصوره المختلفة (الوعي السياسي، الوعي الاجتماعي،

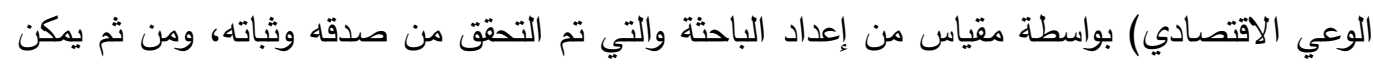
تحديده إجرائًا بواسطة الدرجة الكلية التي يحصل على الطالب نتيجة الاستجابة على مفردات المقياس.

$$
\text { تالثاً- أهداف الدراسةة: تحد البحث الحالي في ست أهداف هم: تحئي }
$$

( ) تحديد مستوى توافر أبعاد المواطنة الرقمية لدى طلاب كلية الخدمة الاجتماعية بجامعة الفيوم.

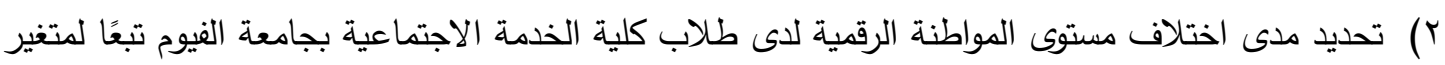

$$
\text { النوع (ذكور / إناث). }
$$

r) تحديد مستوى الوعي الفكري لدى طلاب كلية الخدمة الاجتماعية بجامعة الفيوم.

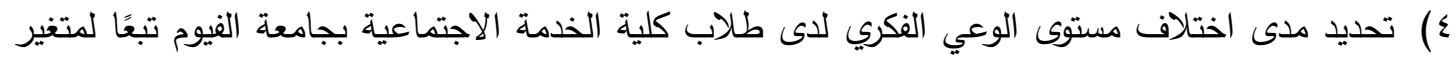

$$
\text { النوع (ذكور / إناث). }
$$


0) الكثف عن العلاقة بين المواطنة الرقمية والوعي الفكري لاى طلاب كلية الخدمة الاجتماعية بجامعة الفيوم.

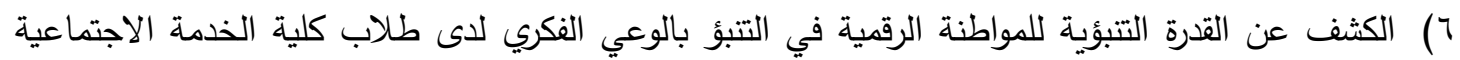
جامعة الفيوم.

$$
\text { تحدد البحث الحالي في ست تساولات الدراسةة: تسؤلات هم: }
$$

() ما مستوى توافر أبعاد المواطنة الرقمية (الاحترام، التعليم، الحماية) لدى طلاب كلية الخدمة الاجتماعية

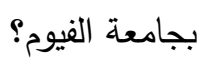

r) ما مدى اختلاف مستوى المواطنة الرقمية لدى طلاب كلية الخدمة الاجتماعية بجامعة الفيوم تبعًا لمتغير

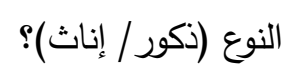

r) ما مستوى الوعي الفكري لاى طلاب كلية الخدمة الاجتماعية بجامعة الفيوم؟

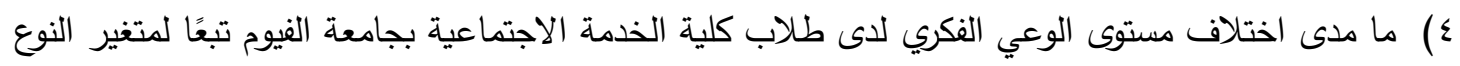

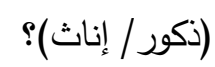

0) ما العلاقة بين المواطنة الرقمية والوعي الفكري لدى طلاب كلية الخدمة الاجتماعية بجامعة الفيوم؟ ا) ما القدرة التتبؤية لأبعاد المواطنة الرقمية في التتبؤ بالوعي الفكري لاى طلاب كلية الخدمة الاجتماعية

بجامعة الفيوم؟ مان

خامسًا - الإطار النظري للدراسةة:

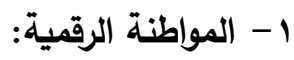

أ- أهمية المواطنة الرقمية

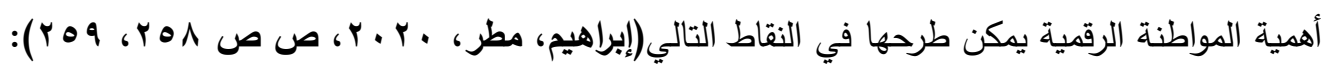

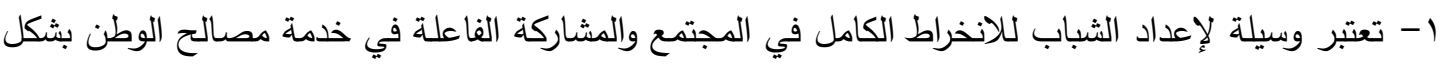

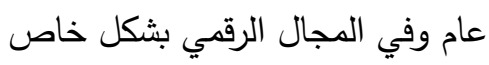

r- ضمان أكبر لممارسات آمنة في إطار من المسئولية القانونية والأخلاقية للمعلومات والتكنولوجيا.

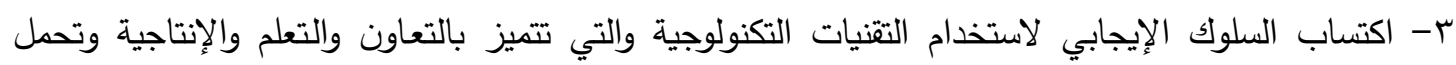
المسئولية الثخصية عن التعلم مدى الحياة. ع- تكوين المواطن الرقمي والمحاط بأطر أخلاقية تحميه من مخاطر إثاعة الأفكار المضللة عبر التقنيات التكولوجية.

ه- إن تعزيز المواطنة الرقمية ينعكس بثكل إيجابى على تعزيز مواطنة الأفراد في أوطانهم الحقيقية فهي

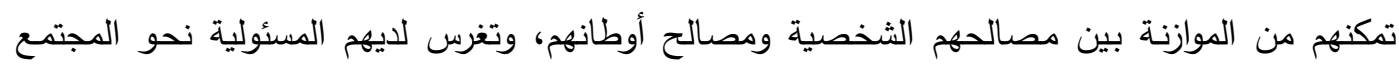
والدفاع عنه ومشاركة تحدياته المعاصرة ورؤاه المستقبلية. ب- خصائص المواطنة الرقمية

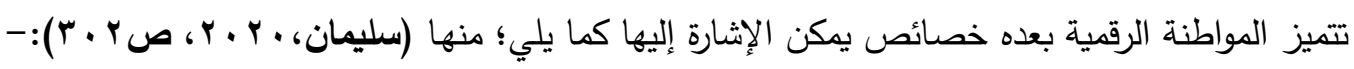

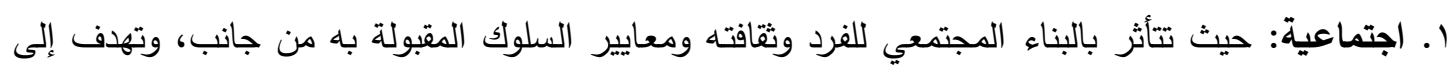

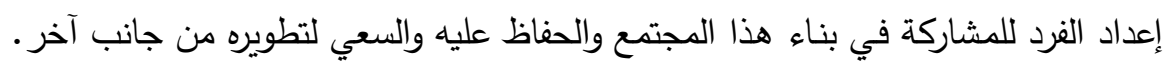


r. ذات طابع انفعالي وجداني: ويظهر ذلك في فهم ومناقشة القضايا الإنسانية في العالم الرقمي، والمعايير

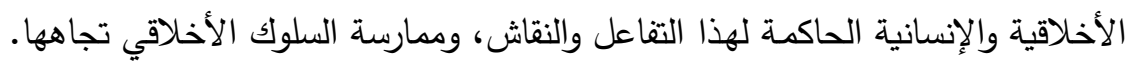

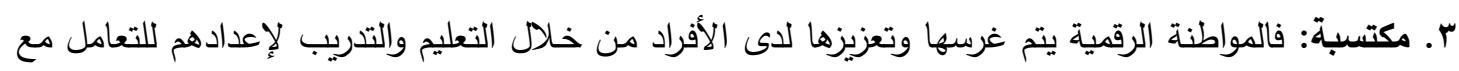
المجتمعات الرقمية.

ع . نسبية: حيث تختلف بين الأفراد باختلاف قدراتهم العقلية والفكرية واهتماماتهم ومصالحهم الثخصية وأدواتهم لمتواصل بالمجتمع الرقمي. ه. قابلة للقياس: حيث يمكن الكثف عن مدى توافر ها لاى الأفراد من خلال ممارساتهم وسلوكياتهم وآرائهم حول التفاعل عبر المجتمعات الرقمية. ج- أهداف تنمية المواطنة الرقية لاى الثباب الجامعي: الثعايه

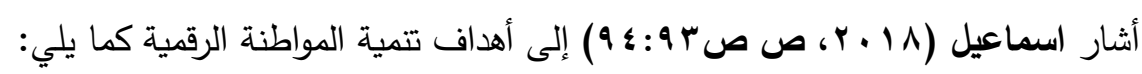

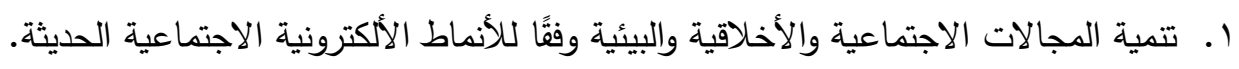
r. السعي في نشر ثقافة التعامل الحضاري مع التكنولوجيا المتطورة والأبعاد القانونية لاستخداماتها. r. التركيز على الجانب الإيجابى للثورة الرقمية التي تساعد على التعامل مع المستقبل الرقمي.

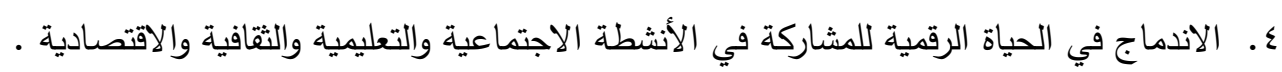

0. تعزيز احترام مفاهيم الخصوصية وحرية التعبير في العالم الرقمي وربطها بالهوية الوطنية.

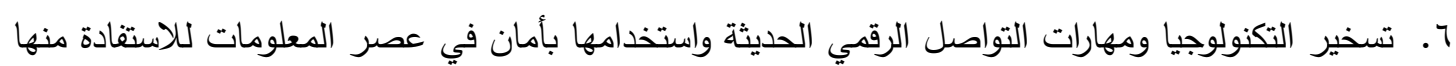

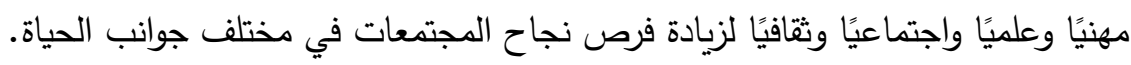

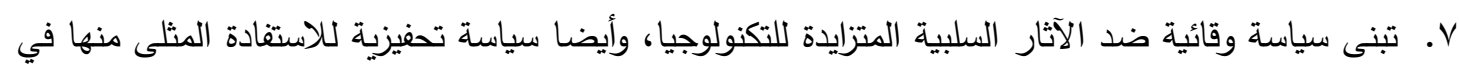
بناء مجتمع المعرفة.

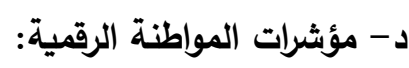
1. مؤشر الاحترام احترم نفسك/ احترم الآخرين: تستتد إلى العناصر التي تعزز مبادئ الاحترام لدى الفرد،

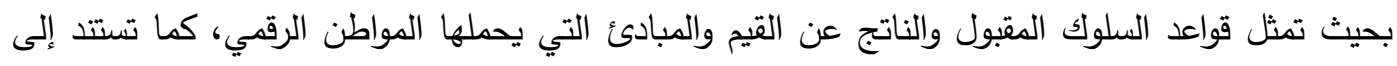
أهمية تمكين جميع الفئات في المجتمع من استخدام التقنيات الرقمية.

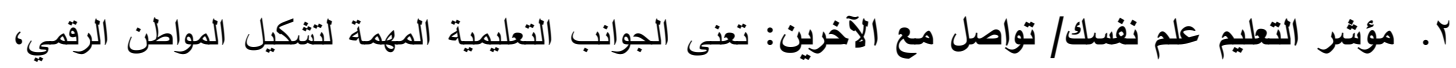

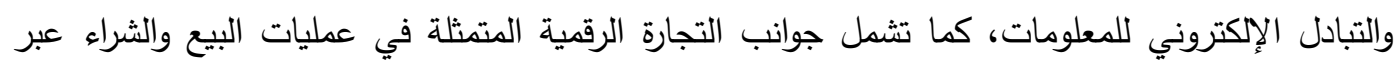
الإنترنت.

r. مؤشر الحماية احم نفسك/ احم الآخرين: تثير إلى عناصر الحماية، مثل الحماية الثخصية والنفسية،

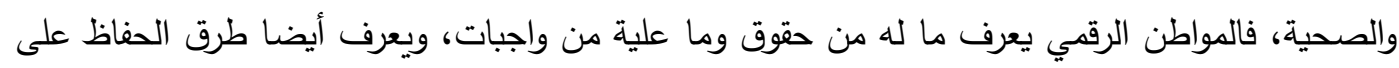

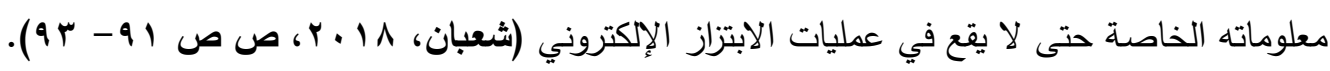

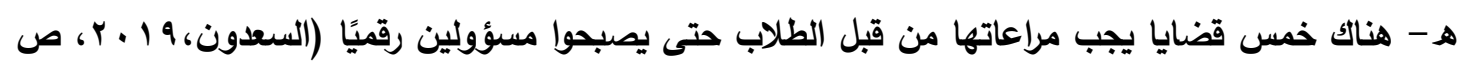
$:(r \wedge \varepsilon$ ، $r \wedge r$

1. التوازن: ويعنى وجود الموازنه بين الفرص والمسؤوليات والموازنة بين تحقيق الذات والانتماء للمجتمع.

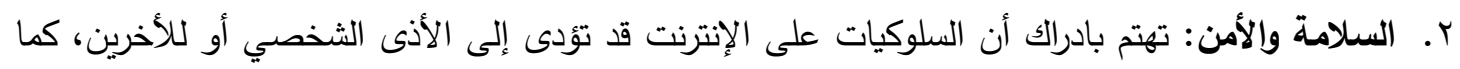
تعنى احترام خصوصية الآخرين وإدراك المواقع الإلكترونية غير الملائمة. r. التنمر: ويستتد إلى فهم الآثار السلبية للتتمر عبر الإنترنت، وإدراك أنه انتهاك للمبادئ الأخلاقية. 
ع. المواد الإباحية: وتعنى فهم الآثار السلبية لاستخدام الهاتف المحمول والمجتمعات الافتراضية الأخرى لالتقاط وبث الصور من هذا النوع.

ه. حقوق التأليف والنشر والانتحال: وتعنى احترام حقوق الملكية الفكرية للآخرين والوعي بأن استخدام المحتوى والمواد المتوافرة على الإنترنت دون إذن يعد غير قانوني وغير أخلاقي.

$$
\text { أ- أهمية الوعي الفكري: الفكري: }
$$

يتضمن الوعي الفكري مجموعة من الأفكار والتصورات والمشاعر ، ويختلف الوعي من مجتمع لأخر

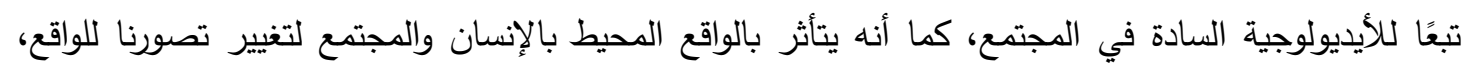

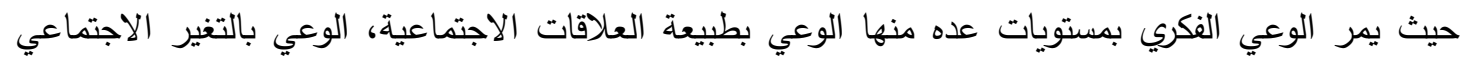
المقصود وكذلك الوعي بالبيئة المحيطة والوعي بضرورة وجود أيديولوجية وثقافة متغيرة ويككن تلخيص أهمية

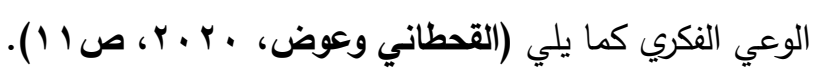

يزود الطلاب بالمعلومات والخبرات والمهارات التي تساعده على الانتفاع بالموارد الإنتاجية. يدرب الطلاب على مواجهة مواقف الحياة ومشكلاتها اليومية عن طريق اتخاذ القرارات السليمة وتتفيذها

$$
\text { بأسلوب علمي. }
$$

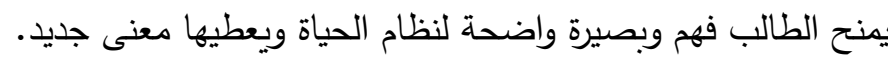

$$
\text { يساعد على القضاء على الارتجالية والفوضى في شئون الحياة. }
$$

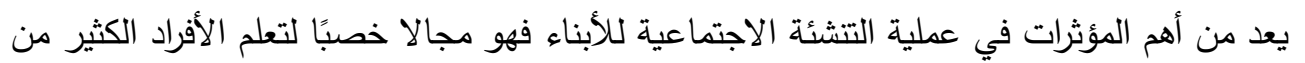
مبادئ السلوك الاجتماعي والمشاركة الاجتماعية، وكذلك تعلمهم القيم التي تدور حول التعاون والمشاركة

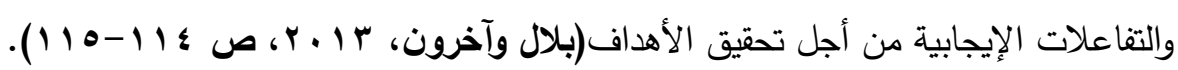

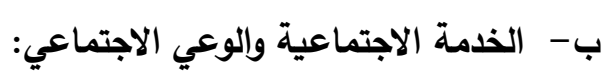

يعنى الوعي الاجتماعي كأحد أبعاد الوعي الفكري في المجتمع الجامعي معرفة الإنسان بحقوقه وواجباته

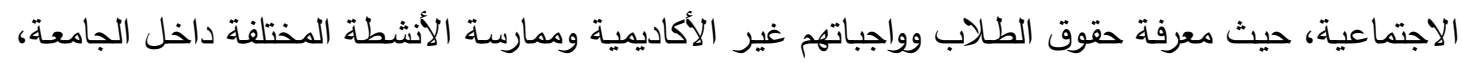

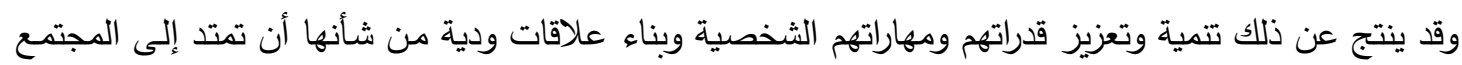

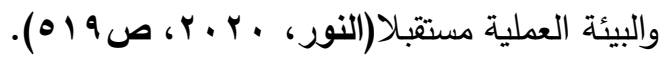

$$
\begin{aligned}
& \text { ج- الوعي السياسي لاى الثباب الجامعي: }
\end{aligned}
$$

يعد الوعي السياسي محصلة من القيم والمبادئ السياسية التي تتيح للفرد أن يشارك مشاركة فعالة في أوضاع مجتمعه ومشكلاته، ويحللها ويحكم عليها ويحدد موقفه منها ويدفعه إلى التحرك من أجل تطويرها

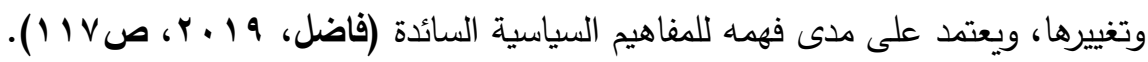
أهمية تعزيز الوعي السياسي (كأحد أبعاد الوعي الفكري) لاى الثباب الجامعي:

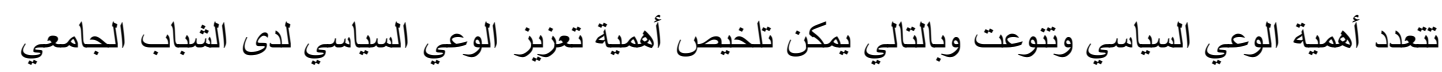

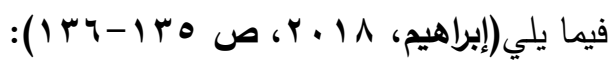

> يساعد الوعي السياسي الطلاب في معرفة الحقوق والواجبات السياسية التي تمنحها الدولة.

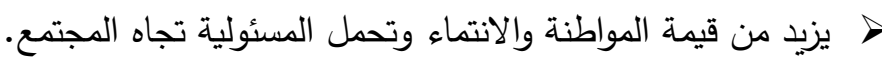
> يثجع الطلاب على القيام بدور نشط في المجتمع التعليمي الرقمي، والحياة المحلية والوطنية، والدولية. 
> يزيد من قدرة الثباب الجامعي على تكوين وجهات النظر الثخصية حول المسائل السياسية، وتبرير آرائهم الخاصة. يقلل من العنف والتعصب والكراهية في نفوس الطلاب. د - الوعي الاقتصادي لاى الثباب الجامعي:

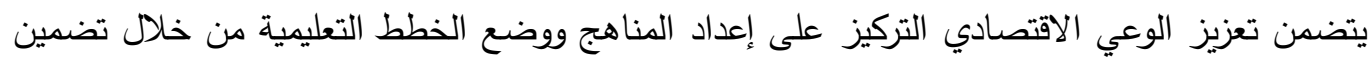

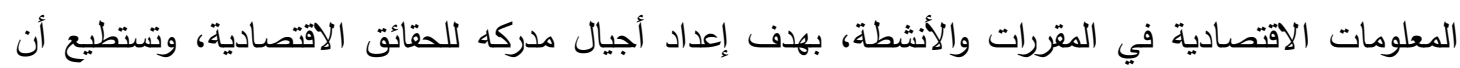
تتعامل معها بإيجابية، ويتعدى دور الوعي الاقتصادي كونه يساهم في القدرة على تحمل المسئولية، واحترام قيمة الوقت، وإكساب الطلاب القيم الاقتصادية وغير ذلك من القيم التي تؤثر في سلوكهم الاقتصادي ومجتمعهم

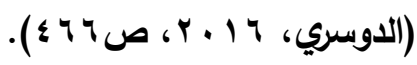
وفيما يلي بعض المؤشرات الواجب مراعاتها لتعزيز الوعي الاقتصادي (كأحد أبعاد الوعي الفكري) لدى (على (الدي

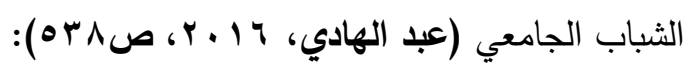

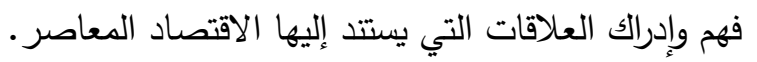
إكساب المتعلم الحقائق والمفاهيم الاقتصادية المعاصرة. زيادة الوعي لاى الطلاب للمساهمة في تقليل الفاقد خلال الاستهلاك لتقليليل الأعباء الاقتصادية. زيادة الوعي بأهمية الادخار والتوعية بآثاره الإيجابية. تزويد واكساب الطلاب بالقيم والمبادئ التي تمكنهم من تحديد الخيارات الاقتصادية الصحيحة.

\section{سادسًا - الإجراءات المنهجية للاراسة:}

1- نوع الدراسة: تُعد هذه الدراسة من الدراسات الوصفية، وقد تم اختيار الباحثة لهذا النوع من الدراسات؛ نظراً

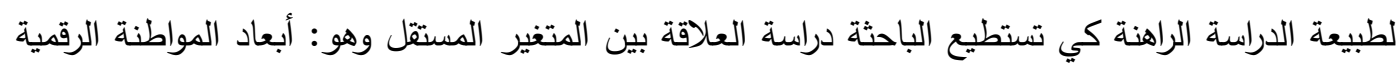

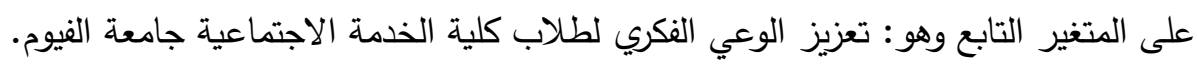

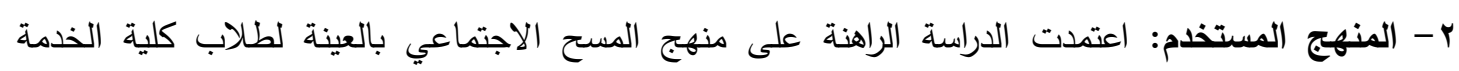
الاجتماعية جامعة الفيوم. الفمات

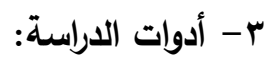
تم تطوير مقياسين للإجابة عن تساؤلات الدراسة هما:

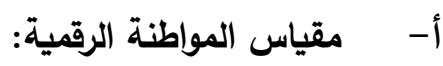
قامت الباحثة بمسح الأدبيات والدراسات السابقة العربية والأجنبية المتعلقة بمتغير المواطنة الرقمية لإعداد

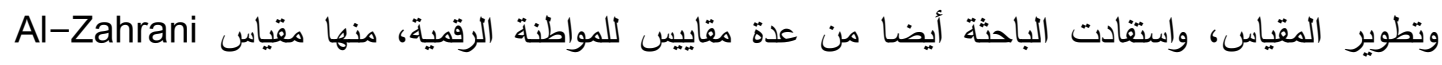
(2015)، وأدت هذه المراجعة إلى تحديد المحاور الأساسية التي يتم عليها بناء مفردات المقياس بصولة بصورته

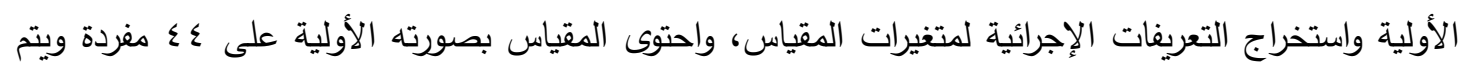

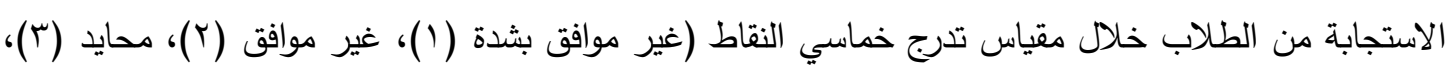

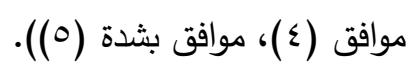




$$
\text { ب- مقياس الوعي الفكري: }
$$

راجعت الباحثة أيضا عديد من الأدبيات والدراسات السابقة العربية والأجنبية المتعلقة بالوعي الفكري

وخصوصا لدى الثباب، وأيضا اطلعت على عدة مقاييس للاستفادة منها مقياس (2020) .Molotova et al.

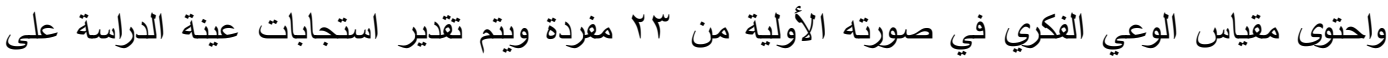

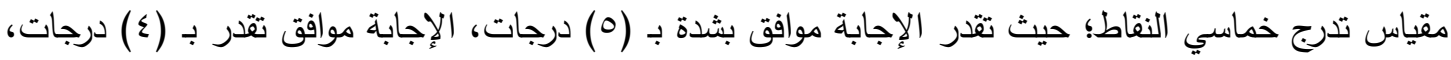
ومحايد تقدر بـ (r) درجات، وغير موافق بدرجتين وأخير غير موافق بثدة بدرجة واحدة فقط.

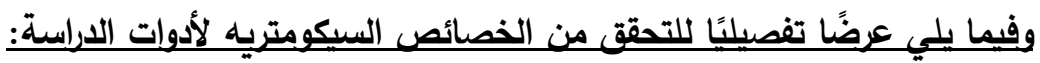
أ- مقياس المواطنة الرقمية: • الصدق الظاهري: تم فحص المقياس بواسطة عدد (0) من أعضاء هيئة التدريس بجامعة الفيوم، وذلك للتحقق من الصدق الظاهري للمقياس. وأجريت العديد من التعديلات على صياغة المفردات وفق التغذية

$$
\text { الراجعة من السادة المحكمين. }
$$

الصدق العاملي للمقياس: أجري التحليل العاملي الاستكثافي(EFA) Exploratory factor analysis (لرنين للتعرف على البنية العاملية للمقياس باستخدام طريقة المكونات الأساسية، واستخدم محك التشبع • بـ.

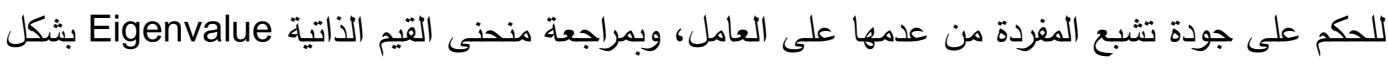
( (1)، نجد أن المقياس يحتوي على ثلاث عوامل أساسية، وهذا ما يتفق مع البنية النظرية للمقياس.

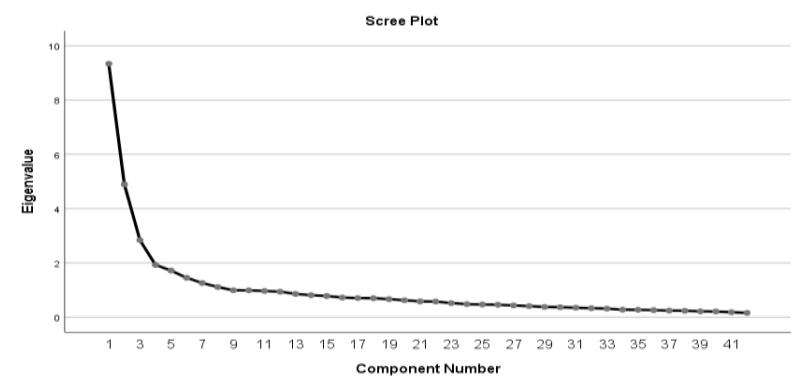

\section{شكل (1) القيم الأتية لعوامل مقياس المواطنة الرقمية}

وتم إعادة التحليل العاملي مرة أخرى لتدوير مفردات المقياس على ثلاث عوامل باستخدام طريقة

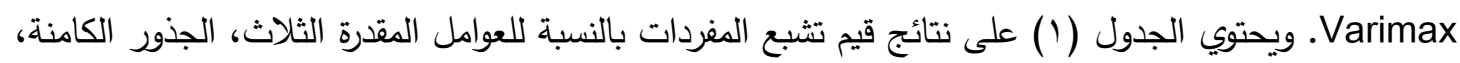
مؤشر كفاية العينة KMO وأخيرا مؤشر كفاية بنية الارتباط لبارتليت.

\begin{tabular}{|c|c|c|c|c|c|}
\hline \multicolumn{2}{|c|}{ العامل الثالث: الحماية } & \multicolumn{2}{|c|}{ العامل الثاني: التعليم } & \multicolumn{2}{|c|}{ العامل الأول: الاحتر ام } \\
\hline$\cdot, 0 . \mathrm{V}$ & المفردة اب & $\cdot, \Sigma \wedge \mu$ & المفردة سا & $\cdot, M \wedge$ & المفردة 1 \\
\hline$\cdot, \leqslant 9 \leqslant$ & المفردة بr & $\cdot, 7 \cdot 9$ & المفردة ع 1 & $\cdot, \Pi \wedge I$ & المفردة ب \\
\hline$\cdot, 0 \leq 7$ & المفردة سT & $\cdot, 09 \varepsilon$ & المفردة 10 & $\cdot, \leqslant) V$ & المفردة ب \\
\hline$\cdot, \leqslant Y 0$ & المفردة ع &., 771 & المفردة 7 ا & $\cdot, r \cdot V$ & المفردة 0 \\
\hline$\cdot, \leqslant 0 \leqslant$ & المفردة هب & $\cdot, V \cdot \Lambda$ & المفردة IV & $\cdot, \leqslant 9 \wedge$ & المفردة 7 \\
\hline$\cdot, \leqslant 9 \leqslant$ & المفردة بr & $\cdot, 710$ & المفردة 1 ا & $\cdot, 0 \wedge$. & المفردة V \\
\hline$\cdot, 0 Y 1$ & المفردة VT & $\cdot, \vee>0$ & المفردة 9 ا & $\cdot, \leqslant \vee 7$ & المفردة 1 \\
\hline$\cdot, T \leqslant Y$ & المفردة ^ץ &., 007 & المفردة · ب & $\cdot, 7 \cdot V$ & المفردة 9 \\
\hline$\cdot, 001$ & المفردة qج & $\cdot, 07 \pi$ & المفردة اب & $\cdot, \Pi \wedge I$ & المفردة 1 \\
\hline$\cdot, 717$ & المفردة · ع & $\cdot, 7) \wedge$ & المفردة بr & $\cdot, r V I$ & المفردة I 1 \\
\hline$\cdot, 0 \leqslant \Gamma$ & المفردة اء & $\cdot, \leqslant \wedge \neg$ & المفردة سب & & \\
\hline$\cdot, 09 \mathrm{~V}$ & المفردة بـ & $\cdot, 0 \wedge \mathrm{V}$ & المفردة ع ب & & \\
\hline י, & المفردة بـ & $\cdot, 7 \leqslant 0$ & المفردة 0ب & & \\
\hline
\end{tabular}

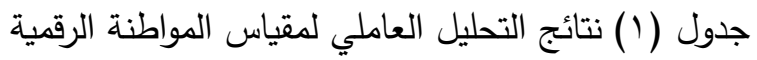




\begin{tabular}{|c|c|c|c|c|c|}
\hline \multicolumn{2}{|c|}{ العامل الثالث: الحماية } & \multicolumn{2}{|c|}{ 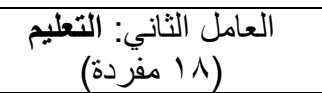 } & \multicolumn{2}{|c|}{ العامل الأول: الاحترام } \\
\hline \multirow[t]{5}{*}{$\cdot, \Sigma \vee Y$} & المفردة عـ & $\cdot, \vee \vee \varepsilon$ & المفردة جاب & & \\
\hline & & $\cdot, V Y Y$ & المفردة TV & & \\
\hline & & $\cdot, T V V$ & المفردة rی & & \\
\hline & &., $0 \wedge 7$ & المفردة 9 ب & & \\
\hline & & $\cdot, \Sigma T r$ & المفردة • r & & \\
\hline & & & & & \\
\hline$r, \wedge \varepsilon$ & & $\varepsilon, 19$ & & $9, \pi \leq$ & الجذر الكامن \\
\hline \multirow[t]{3}{*}{$7, \vee \vee T$} & & 11,77 & & $Y Y, Y \leq$ & التباين المفسر \\
\hline & & & & $\varepsilon \cdot, 70$ & مجموع التباين \\
\hline & & & & $\cdot, \wedge \mathrm{V}$ & KMO \\
\hline \multicolumn{5}{|c|}{$x^{2}(861)=4421.624, p<.01$} & Bartlett \\
\hline
\end{tabular}

$$
\text { وتثير النتائج الموجودة في جدول ( () إلى الآتي: }
$$

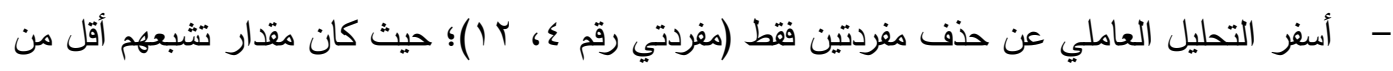
.,$\Gamma$.

- العامل الأول والمسمى بـ الاحترام (احترم نفسك واحترم الآخرين) يتكون من • • مفردات بقيم تثبع

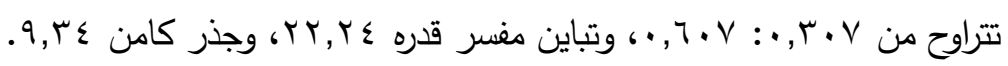

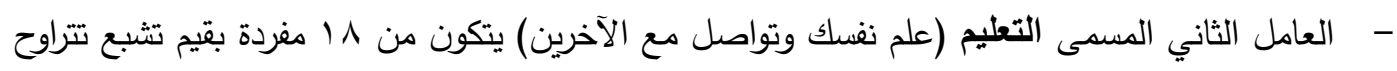

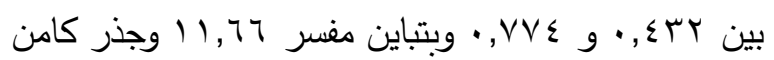

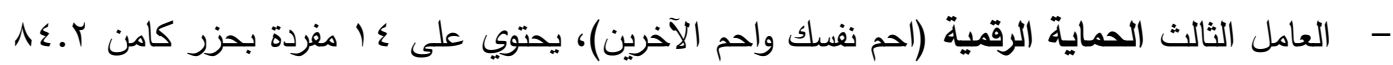

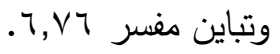

- - تحقق ملاءمة كل مؤشر كفاية العينة (KMO)، ومؤشر كفاية بنية الارتباط (بارتليت). ثبات المقياس: يعرض الجدول (r) قيم ثبات مقياس المواطنة الرقمية لكل بعد على حده والمقياس ككل بلى

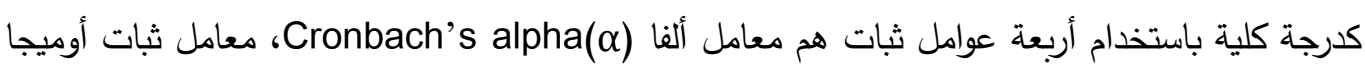
McDonald’s omega

.Guttman's Lambda

جدول (r) قيم ثبات مقياس المواطنة الرقمية

\begin{tabular}{|c|c|c|c|c|}
\hline كبل & البعد الثالث: & البعد الثاني: & الاحعد الأول: & \\
\hline$\cdot, \wedge 91$ & $\cdot, \wedge 7$. & $\cdot, 91 r$ & $\cdot, 7 \vee \varepsilon$ & omegaثبات اوميجا \\
\hline$\cdot, 979$ & $\cdot, 9 \times 7$ & $\cdot, 971$ & $\cdot, \wedge)$. & Greatest lower bound \\
\hline -, $9 \leq$. & $\cdot, \wedge \wedge \varepsilon$ & $\cdot, 9 M r$ & $\cdot, v \leq 0$ & Guttman's Lambda \\
\hline$\cdot, \wedge 94$ & $\cdot, \wedge 7$. & $\cdot, 91$. & $\cdot, 7 \wedge \wedge$ & ثبات ألفا م \\
\hline
\end{tabular}

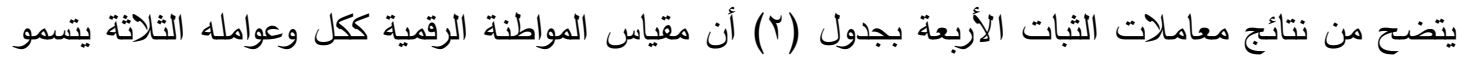
بثبات جيد.

تصحيح المقياس: يتم تقدير الاستجابات وفق تقدير ليكرت الخماس [أوافق بثدة (0) درجات، أوافق (ع)

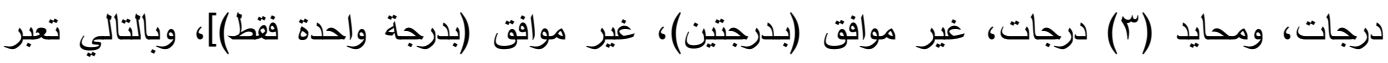

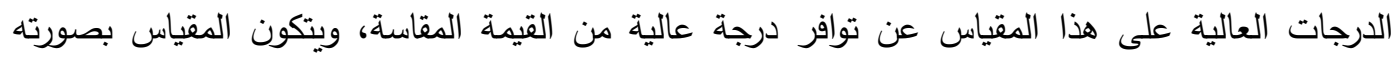

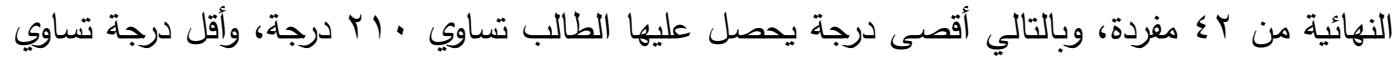


ب- مقياس الوعي الفكري: ه الصدق الظاهري: تم التحقق من الصدق الظاهري للمقياس من خلال (0) من أعضاء هيئة التدريس، وتم تعديل صياغة بعض مفردات المقياس وفق التغذية الراجعة من المحكمين.

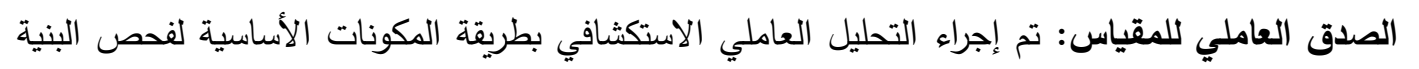

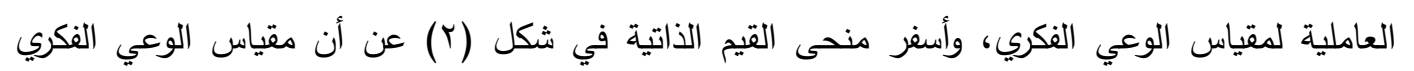
يحتوي على عامل واحد.

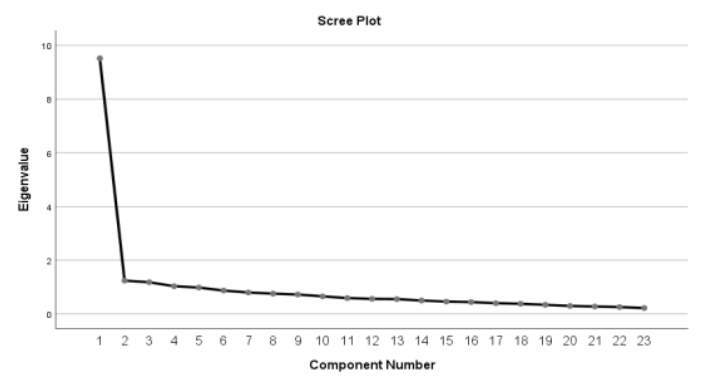

$$
\text { شكل (ץ) القيم الذاتية لمقياس الوعي الفكري }
$$

ويعرض جدول (r) نتائج التحليل العاملي الاستكثافي لمقياس الوعي الفكري، وباستقراء نتائج هذا

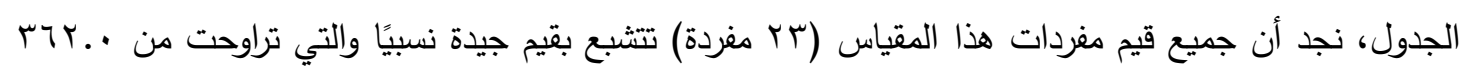

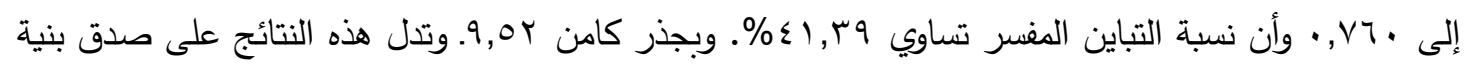

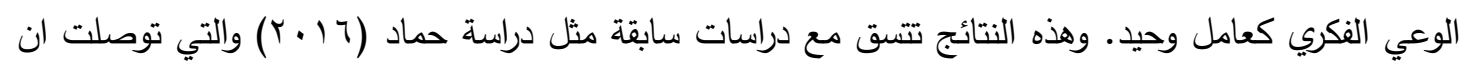
الوعي الفكري يحتوي فقط على عامل واحد. جدول (ץ) نتائج التحليل العاملي الاستكثافي لمقياس الوعي الفكري

\begin{tabular}{|c|c|c|c|}
\hline 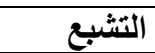 & المفردات & التشبع & المفردات \\
\hline$\cdot, T / Y$ & المفردة سا & $\cdot, 7 \leqslant$. & المفردة I \\
\hline$\cdot, \mathrm{V} O \mathrm{~V}$ & المفردة ؟ ا & $\cdot, V \leqslant 7$ & المفردة r \\
\hline . & المفردة 10 & $\cdot, 799$ & المفردة r \\
\hline$\cdot, \mathrm{V} O \mathrm{~N}$ & المفردة 17 &., 090 & المفردة ؟ \\
\hline$\cdot, 771$ & المفردة VV & ס סזר, & المفردة 0 \\
\hline$\cdot, \vee \vee q$ & المفردة 11 & $\cdot, 7 \leqslant 9$ & المفردة 7 \\
\hline$\cdot, v \ldots$ & المفردة 19 & $\cdot, 0 \wedge 1$ & المفردة V V \\
\hline., $0 . r$ & المفردة · r & $\cdot, \varepsilon \pi T$ & المفردة 1 \\
\hline$\cdot, 0 Y 1$ & المفردة إ Y & $\cdot, 7 \wedge 9$ & المفردة 9 \\
\hline., $0 \wedge \mathrm{V}$ & المفردة rY & $\cdot, 7 \leqslant \varepsilon$ & المفردة • 1 \\
\hline \multirow[t]{5}{*}{$\cdot, 091$} & المفردة سب & $\cdot, V M T$ & المفردة ل 1 \\
\hline & & $\cdot, \mathrm{V} 4$. & المفردة r| \\
\hline & & 9, or & قيمة الجذر الكامن \\
\hline & & $\% \leqslant 1, r q$ & نسبة التباين المفسر \\
\hline & & $\cdot 94$ & معامل KMO \\
\hline \multicolumn{3}{|c|}{$x^{2}(253)=2488.518, p<.01$} & Bartlett معامل بارتليت \\
\hline
\end{tabular}


التحقق من ثبات المقياس: يعرض جدول (ع) القيم المقدرة لمعاملات ثبات مقياس الوعي الفكري باستخدام

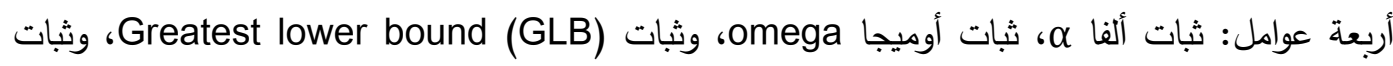

.Guttman's Lambda

جدول (؛) نتائج ثبات مقياس الوعي الفكري

\begin{tabular}{|c|c|}
\hline مقدار الثبات & معامل الثبات \\
\hline$\cdot, 949$ & ثcات اوميجاacDonald's omega \\
\hline$\cdot, 970$ & Greatest lower bound (GLB) \\
\hline$\cdot, 9 \leq \varepsilon$ & Guttman's Lambda \\
\hline$\cdot, 949$ & 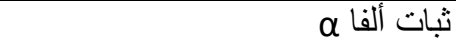 \\
\hline
\end{tabular}

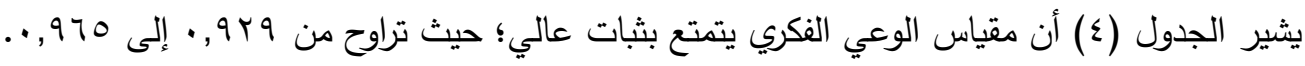

تصحيح المقياس: يتم تقدير الاستجابات وفق تقدير ليكرت الخماسي؛ بمعنى أن أوافق بشدة تقدر بـ (0)

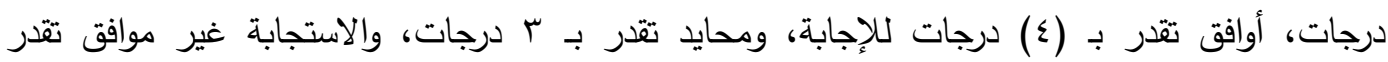

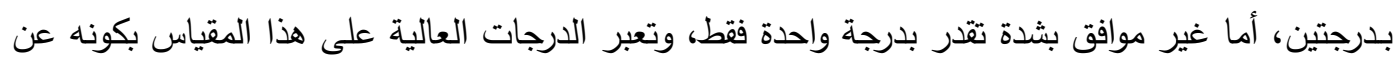

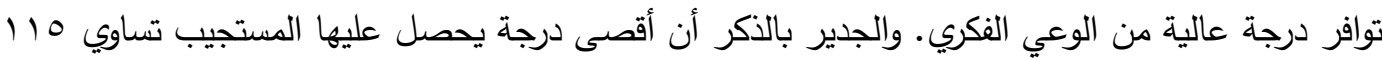

درجة.

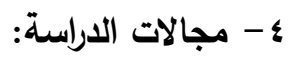

أ- المجال المكاني: طبقت أدوات الدراسة الحالية على عينة عشوائية من طلبة وطالبات كلية الخدمة

الاجتماعية بفرقها المختلفة وتم التطبيق الإلكتروني عبر جوجل Google form.

ب- المجال البشري: تألف مجتمع الدراسة من جميع طلبة وطالبات كلية الخدمة الاجتماعية بجامعة الفيوم

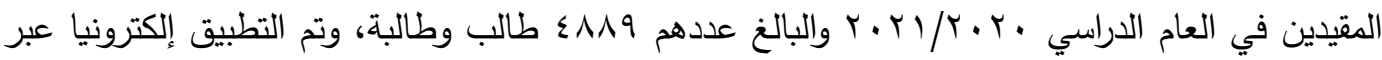

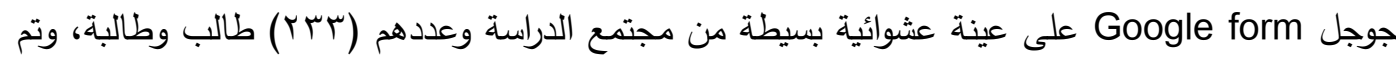

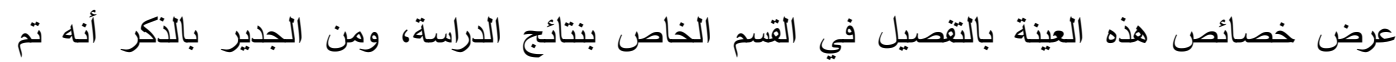

الحصول على موافقة الطلاب على المشاركة في الدراسة الحالية قبل الشروع في تطبيق أدوات الدراسة.

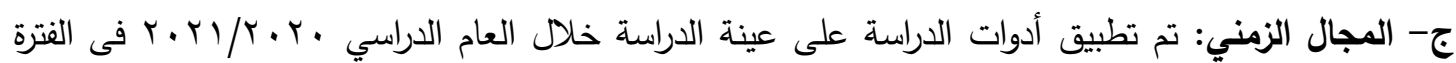

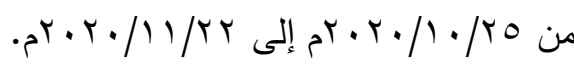

ه- الأساليب الإحصائية المستخدمة:

- - صدق أدوات الدراسة: أجري التحليل العاملي الاستكثافي لفحص البنية العاملية لمقاييس الدراسة الحالية

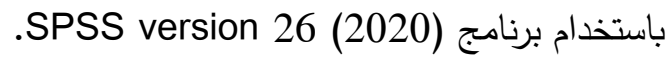

ثبات أدوات الدراسة: تم التحقق من ثبات أدوات الدراسة الحالية باستخدام أربع معاملات ثبات هي: معامل ثبات ألفا Cronbach's alpha( $\alpha$ لكل بعد على حدة والمقياس ككل كدرجة كلية، معامل ثبات أوميجا

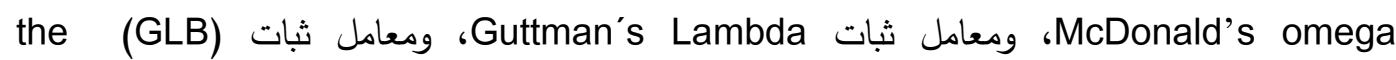
greatest lower bound الحزمة الإحصائية psych) بيرنامج Revelle, 2019, 2020) لتقدير باقي معامل الثبات الأخرى.

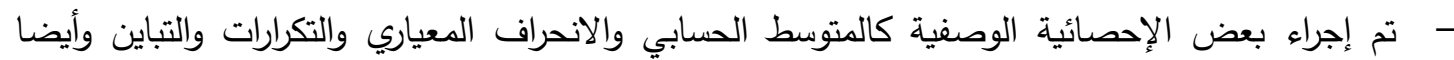
استخدم كل من الالتواء والتفلطح للحكم على مدى اعتدالية بيانات الدراسة. 
- - تم تقدير معامل ارتباط بيرسون لتحديد طبيعة العلاقة بين متغيرات الدراسة الحلية كما استخدمت مخططات الانتشار للتحقق من خطية العلاقة بين متغيرات الدراسة.

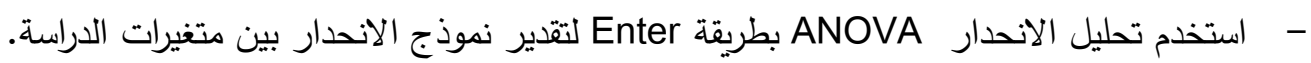

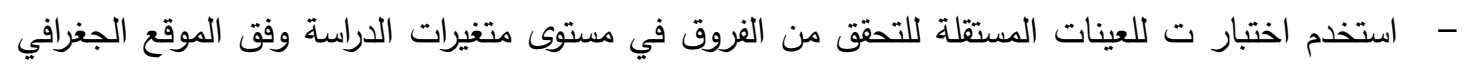
للجمعيات. - - تم الحكم على متوسط استجابات الطلاب على مفردات المقاييس وفق الجدول الآتي:

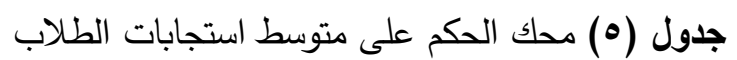

\begin{tabular}{|c|c|}
\hline 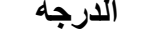 & متوسط تقدير الارجات \\
\hline مرتفعة جدا & $0-\varepsilon, r$. \\
\hline مر تفعة & $\varepsilon, 19-r, \varepsilon$ \\
\hline متوسطة & $r, r q-r, T$ \\
\hline 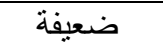 & $r, 09-1,1$ \\
\hline ضعيفة جدا & $1, \vee q_{-} 1$ \\
\hline
\end{tabular}

سابعًا: نتائج الاراسة ومناقشتها:

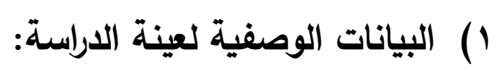

\begin{tabular}{|c|c|c|c|c|c|c|c|}
\hline \multicolumn{3}{|c|}{ ن } & \multicolumn{5}{|c|}{ جدول (†) خصائص عينة الاراسة } \\
\hline$\%$ & 5 & & المتغير & $\%$ & 5) & & المتغير \\
\hline 97,1 & YY & انتظام & \multirow{2}{*}{ الشعبة } & $1 V, 7$ & $\xi 1$ & ذكر & \multirow{2}{*}{ النوع } \\
\hline$r, q$ & 9 & انتساب & & $\Delta Y, \xi$ & 194 & أنثي & \\
\hline $07, Y$ & $1 \pi$ & ريف & \multirow{2}{*}{ الإقامة } & 91,1 & Y) & اعزب & \multirow{2}{*}{ الاجتماعية } \\
\hline$\varepsilon r, \Lambda$ & $1 \cdot r$ & حضر & & $\begin{array}{r}\Lambda, r \\
\%\end{array}$ & 19 & متزوج & \\
\hline & $r \cdot, \cdot T$ & متو سط & \multirow{2}{*}{ 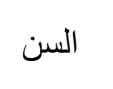 } & $Y V, O$ & $7 \varepsilon$ & الفرقة الاولى & \multirow{4}{*}{ التعليميتوى } \\
\hline & $1, V \cdot Y$ & الانحر اف المعياري & & $7 \pi, 9$ & $1 \leqslant 9$ & الفرقة الثانية & \\
\hline & & & & $1, \mathrm{~V}$ & $\varepsilon$ & الفر قة الثالثة & \\
\hline & & & & 7,9 & 17 & الفر قة الر ابعة & \\
\hline
\end{tabular}

باستقراء خصائص العينة الموضحة بالجدول (7)، يتضح ما يأتي: - - احتوت عينة الدراسة على بr r من طلبة وطالبات الخدمة الاجتماعية جامعة الفيوم.

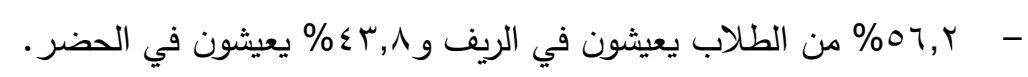

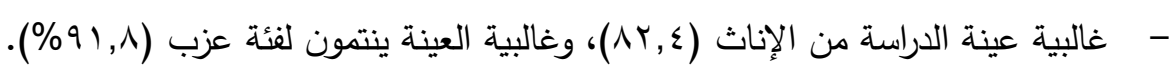

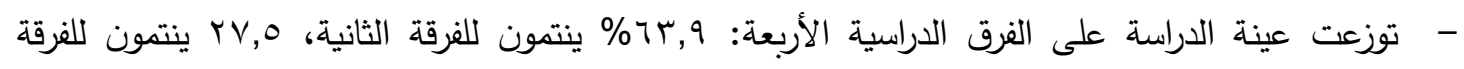

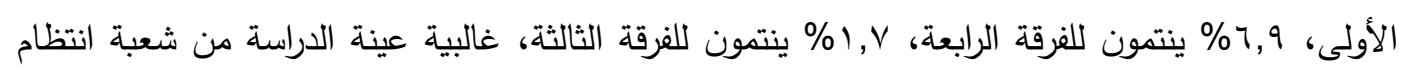
.(\%97, 1)

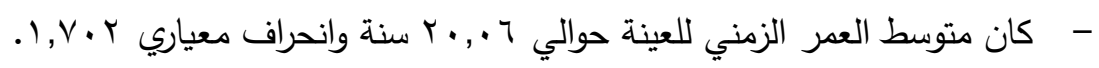


r عرض نتائج الدراسة الحالية وفقاً للتساؤل الأول: والذي ينص على ما مستوى توافر أبعاد المواطنة

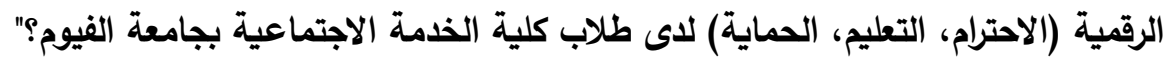

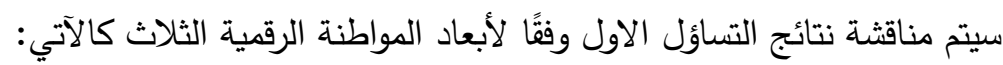
أ) البعد الأول: الاحترام (احترم نفسك واحترم الآخرين) جدول (V) متوسطات درجات استجابات عينة الدراسة حول البعد الأول "الاحترام لنفسك والأخرين" الأحرين

\begin{tabular}{|c|c|c|c|c|}
\hline الوجة & 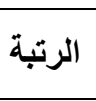 & الاتمرافي & المتوسط & 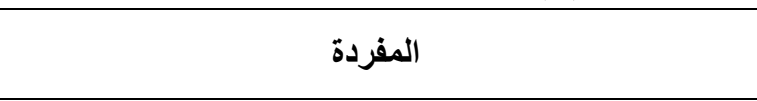 \\
\hline 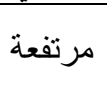 & 9 & $1,01 r$ & $\Gamma, \wedge 0$ & الانستجرام -تويتر) من الجرائم الرقمية. الأخرين بوك-و اتساب-الايميل - الفيس \\
\hline 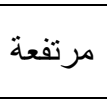 & $\Lambda$ & $1, \cdot 1 r$ & r, 97 & حساباتي الرقتد الى المصادر الرسمية في نشر أي معلومة على \\
\hline 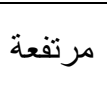 & 0 & $1, r V$ & $\varepsilon$ & الر ـاتصفح الملفات والبيانات الخاصة بالأخرين على أجهزتهم \\
\hline مرتفعة & 11 & 1,07 & $r, \wedge r$ & ع .أحافظ على ملفات الأخرين في الأجهزة الرقمية. \\
\hline 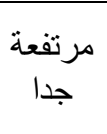 & $r$ & $1, Y_{1}$ & $\varepsilon, \Pi$ & 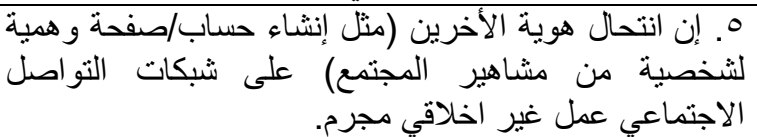 \\
\hline مرتفعة & 1 & $\cdot, 91$ & $\varepsilon, \varepsilon 1$ & 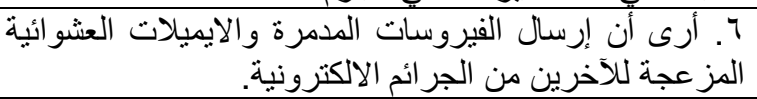 \\
\hline 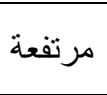 & $V$ & $\cdot, \wedge 9$ & $r, 9 \wedge$ & عبر البيئة الرقمية. حقوق النشر الالكتروني والملكية الفكرية للآخرين \\
\hline مرتفعة & r & $1, \cdot r$ & $\varepsilon, \varepsilon \cdot$ & مأر أوضح أسباب اختلاف وجهة نظري مع الآخرين في البيئة \\
\hline 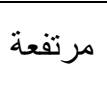 & $\varepsilon$ & $\cdot, \wedge \varepsilon$ & $\varepsilon, 17$ & الرقية لا أشجع الصراع (مثل الإساءة بالألفاظ) داخل البيئة \\
\hline 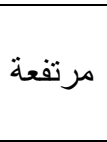 & 7 & $1, \cdot 1$ & r, 99 & 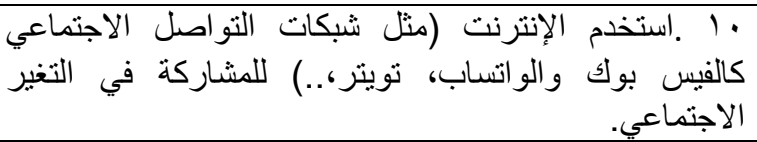 \\
\hline 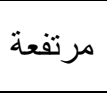 & 1 . & 1,01 & $\Gamma, \wedge 0$ & 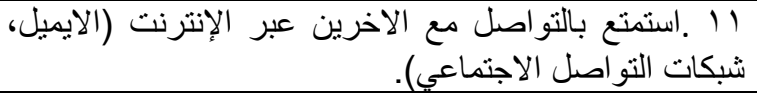 \\
\hline 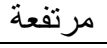 & 9 & 1,17 & $\varepsilon, \cdot V$ & متوسط درجات البعد \\
\hline
\end{tabular}

* هذه العبارة سلبية لذا تم إجراء التقدير بطريقة عكسية لاستجابات الأفراد.

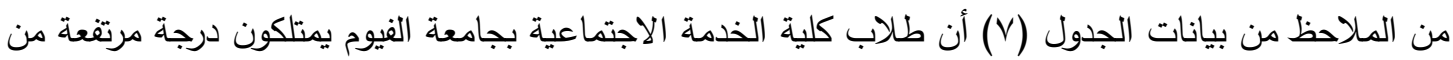

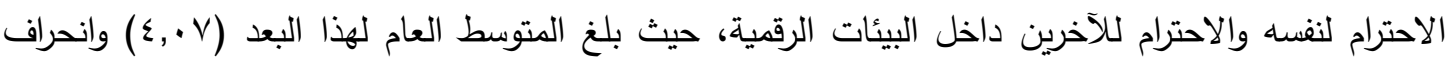

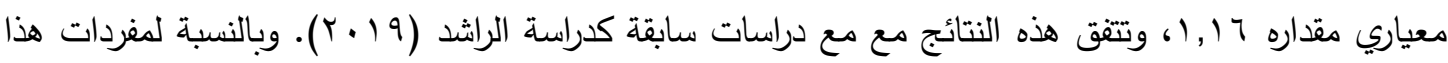
البعد، أن متوسط درجات جميع مفرادت هذا البعد مرتفعة أو مرتفعة جدًا، حيث جاءت درات المفردة رقم 7 في المرتبة

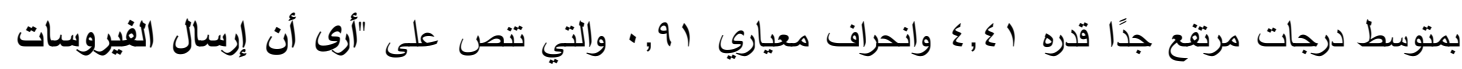

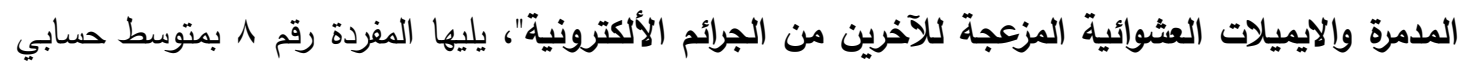

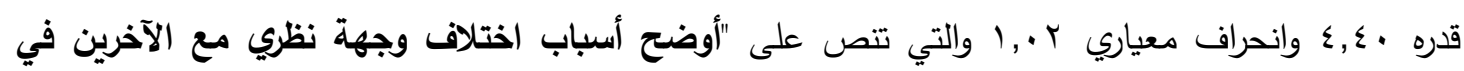

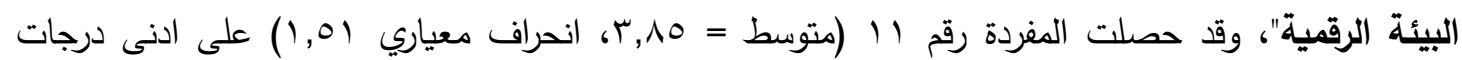
الموافقة مقارنة ببقية مفردات هذا البعد، والتي تتص على "استمتع بالتواصل مع الآخرين عبر الإنترنت (الإيميل، شبكات التواصل الاجتماعي)"، وقد يرجع ذلك إلى دور كليات الخدمة الاجتماعية في تتمية الأخلاقيات 
ب-البعد الثاني: التعليم Educate (علم نفسك وتواصل مع الآخرين) جدول (^) متوسطات درجات استجابات عينة الدراسة حول البعد الثاني "التعليم"

\begin{tabular}{|c|c|c|c|c|}
\hline الو الوعية & الرتبة & المعياري & المتوسط & المفردة \\
\hline متوسطة & $\pi$ & $1, \pi$ & 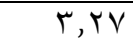 & با ا. لدي حساب مفعل على بنك المعرفة المصري. \\
\hline مرتفعة & 9 & 1,19 & $r$, or & المصري. أستطيع البحث عن المصادر التعليمية في بنك المعرفة \\
\hline 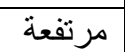 & 0 & $1, \cdot \varepsilon$ & $r, \Lambda$. & 10 أجيد التعامل مع التطبيقات الرقمية كالبريد الالكتروني. \\
\hline متوسطة & 17 & $1, r V$ & $r, 97$ & كو م). أثشتري منتجات/سلع من المتاجر الالكترونية (مثل سوق دوت \\
\hline متوسطة & $1 \leq$ & $1, Y V$ & $r, Y$ & V V . يعطيني التسوق الاكتروني خيار ات أفضل للثر اء. \\
\hline مرتفعة & $1 \cdot$ & $1, r$ & $r$, or & المختلفة من حيث أقارن السنتجات التي ارغترة الضمّان ومدة ائها إلكترونيا في المنتج. المتاجر \\
\hline متوسطة & 10 & $1, \mathrm{r} \wedge$ & $r, .1$ & أمازون،...). 1 استخدم مواقع التسوق الإلكتروني (مثل سوق كوم، \\
\hline منوسطة & IV & $1, Y \wedge$ & r,AY & •r. التسوق الالكتروني أفضل لي من الذهاب إلى السوق. \\
\hline متوسطة & 11 & $1,1 \mathrm{~V}$ & $r, 79$ & اب. لدي ثقة في الثراء عبر الإنترنت. \\
\hline مرتفعة & r & $1, .7$ & $\varepsilon, .1$ & 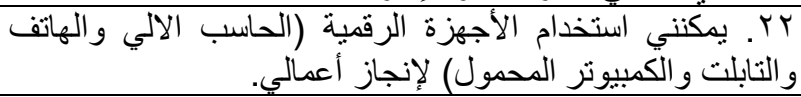 \\
\hline مرتفعة & 1 & $1, \cdot \varepsilon$ & $\varepsilon, 1 Y$ & مساعدة. يمكنني تحميل البرامج التي اريدها من شبكة الإنترنت دون \\
\hline مرتفعة & 1 & $\cdot, 91$ & $\varepsilon, 1\}$ & ع r. أساعد زملائي في الوصول وتحميل البر امج التي يحتاجونها. \\
\hline متوسطة & 11 & $1, Y$ ז & $r, r$ & 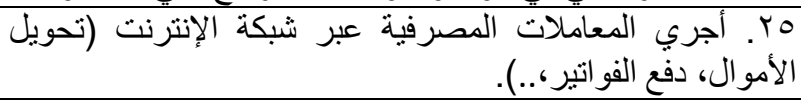 \\
\hline مرتفعة & 7 & $1, r$ & $r, \mathrm{r}$ & 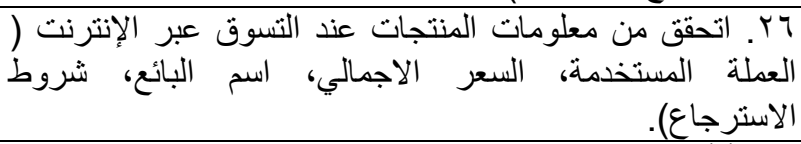 \\
\hline مرتفعة & 0 & $1, Y)$ & $r, \mathrm{r}$ & 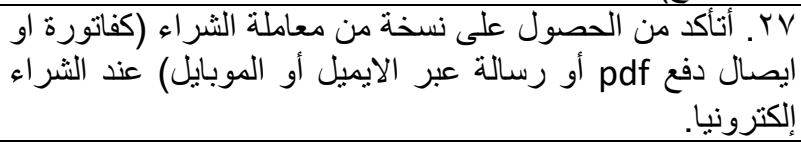 \\
\hline مرتفعة & $r$ & $1, r$. & $r, q \vee$ & 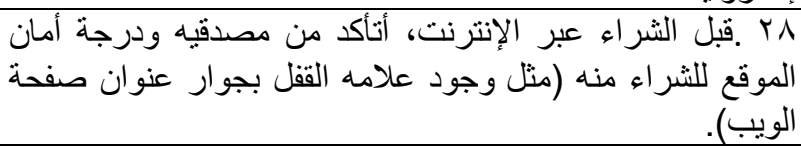 \\
\hline متوسطة & $1 \cdot$ & $1, \leqslant 1$ & $r, r$ & qr .أمتلاك بطاقة بنكيه يمكنني الثر اء بها عبر الإنترنت. \\
\hline مرتفعة & $\mathrm{v}$ & $1,1$. & $r, V Y$ & • • . أنا على در اية بقو انين انتهاك حقوق النشر. \\
\hline 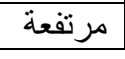 & & 1,19 & $r, \leqslant 9$ & متوسط درجات البعد \\
\hline
\end{tabular}

باستقراء النتائج الموجودة في الجدول رقم (^)، يتضح تباين درجات التعليم المتعلق بالبيئات الرقمية

لاى طلاب الخدمة الاجتماعية، وكان المتوسط العام لدرجات مفردات هذا البعد وفقا لاستجابات عينة الدراسة

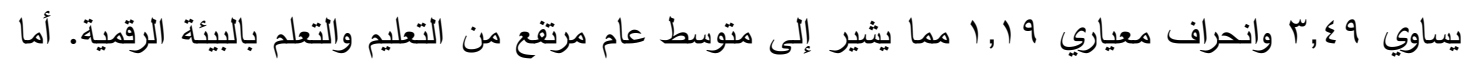

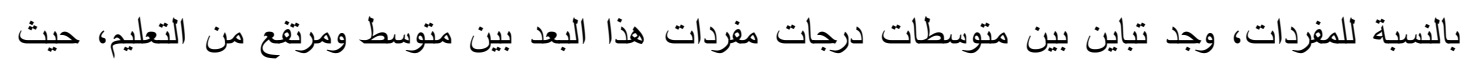

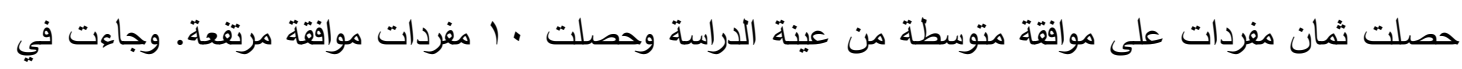

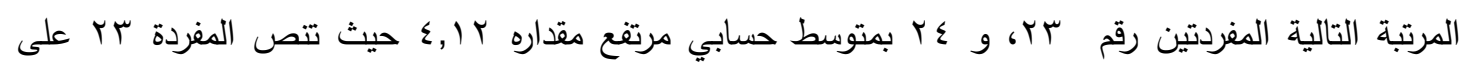

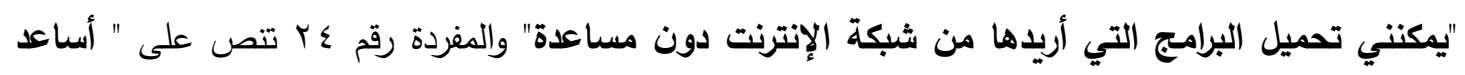

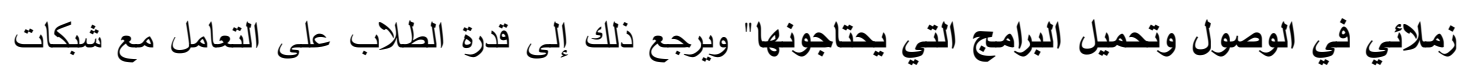
الإنترنت بصورة جيدة والمعرفة الكافية بكيفية تحميل البرامج عبر الإنترنت. 
ومن الجدير بالذكر أن العبارات المتعلقة بالتسوق الأكتروني عبر الإنترنت جاءت في الترتيب الأخير بتقدير متوسط وهم: -

- بالمرتبة ؛ ا، كانت المفردة VI والتي تتص على "يعطيني التسوق الإكتروني خيارات أفضل للشراء. ."

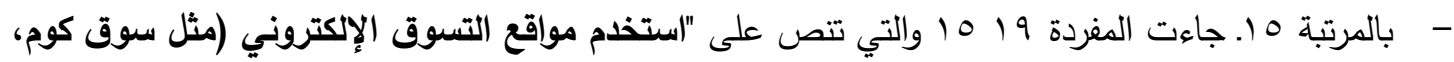

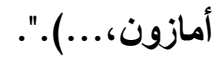

- - بالمرتبة 1 ا، تتواجد المفردة رقم 17 "أشتري منتجات/سلع من المتاجر الأكترونية (مثل سوق دوت

- وبالمرتبة VI ا، جاءت المفردة رقم VI "التسوق الأكتروني أفضل لي من الذهاب إلى السوق.".

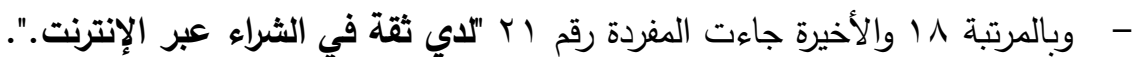
وتدل هذه النتائج على ضعف الثقة لاى الطلاب للثراء عبر الإنترنت وتتفق هذه النتائج دع دراسات سابقة كدراسة شعبان (·r.r. والتي أشارت إلى أن عملية البيع والثراء عبر الإنترنت منخفض لاى الطلاب. وقد يرجع ذلك بسبب ضعف الخدمات والبرامج الإرشادية للطلاب أهمية امتلاك البطاقة البنكية ودورها في سهولة الثراء الألكتروني، وتتقق هذه النتائج مع ما توصلت إليه دراسات سابقة مثل دراسة بوجود قصور في برامج التوجيه والإرشاد لطلاب الجامعة وأنه هناك حاجة ماسة للعمل على توعية الطلاب حول كيفية الحصول الخدمات والمنتجات الالكترونية من المواقع المشهورة، وبشكل عام يتضح حاجه ماسة لتنمية وعي الطلاب بالتجارة الالكترونية.

ج-البعد الثالث: الحماية الرقمية Protect (احم نفسك واحم الآخرين)

جدول (9) متوسطات درجات استجابات عينة الدراسة حول البعد الثالث "الحماية الرقمية"

\begin{tabular}{|c|c|c|c|c|}
\hline 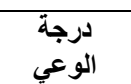 & الرتبة & 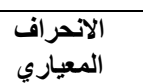 & المتوسط & 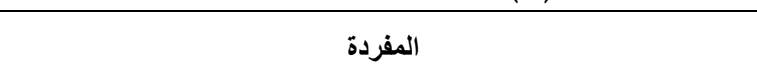 \\
\hline منوسطة & $1 \varepsilon$ & $1, \pi \varepsilon$ & r, ro & باستمر ار. أمتلك برنامج مضاد للفيروسات على أجهزتي الالكترونية وأحدثها \\
\hline 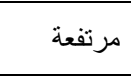 & V & 1,11 & $r, q$. & باستمر ار للحفاظ على خصور حسباتي. الرقمية (الفيس بوك، تويتر، الايميل،...) \\
\hline مرتفعة & 1. & $1,1 \mathrm{r}$ & $r, 7)$ & 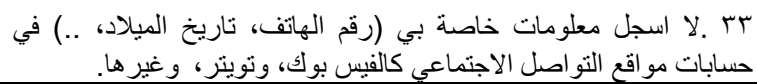 \\
\hline مرتفعة & $\varepsilon$ & $\cdot, 91$ & $\{, 17$ & الاككترونية. أحذف باستمرار البرامج و الملفات غير الضرورية من أجهزتي \\
\hline مرتفعة & $r$ & $\cdot, 94$ & $\mathrm{v}$ & هب. اهتم بزيارة المو اقع الالكترونية الموثوقة والمعروفة. \\
\hline مرتفعة جدا & 1 & $\cdot, 91$ & $\varepsilon, Y \leqslant$ & דr. احذف الرسائل أو الملفات مشبو هة المصدر بدون فتحها. \\
\hline مرتفعة & 0 & $1, \cdot r$ & $\cdot 1$ & VV أقر أ شروط الخصوصبة قبل تثبيت أي برنامج. \\
\hline 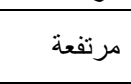 & $\wedge$ & $1,1 \leqslant$ & $r, \wedge \wedge$ & فلاشه، احتفظ بنسخة احتياطية من بياناتي في مكان آمن (هارد خارجي أو \\
\hline 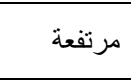 & 7 & $1, \cdot v$ & $r, 90$ & 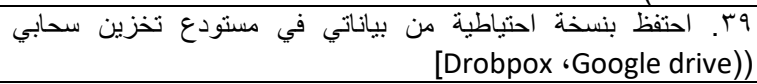 \\
\hline مرتفعة & 9 & $1, \cdot \varepsilon$ & $\Gamma, \wedge \varepsilon$ & •. ـ. استخدم الاجهزة الرقمية باعتدال. \\
\hline 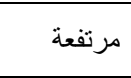 & 11 & $1, r$ & $r, 7)$ & الاماكن لا العامة. معلومات أو بيانات مهمة على اجهزة الحاسب الآلي في \\
\hline مرتفعة & 14 & $1, r^{\prime}$ & $r, \varepsilon r$ & الكمبيوثر الخاص بنتيت وتحديث برنامج مكافحة التجس antispy على جهاز \\
\hline 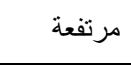 & ir & $1, Y$ & $r, 00$ & rاء. أهتم بتشغيل جدار الحماية firewall على جهاز الكمبيوتز الخاص بي. \\
\hline 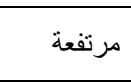 & r & $\cdot, 9 \vee$ & $\varepsilon, 19$ & (الإدمان ـ التوتر ـ القخر الصحية نتيجة الإفر اط في استخدام التقنيات الرقمية مثل \\
\hline مرتفعة & & 1,1 & $r, \wedge \bullet$ & متوسط درجات البعد \\
\hline
\end{tabular}


يعرض جدول (9) متوسطات التقدير لمستوى “الحماية الرقمية” لاى طلاب الخدمة الاجتماعية، وكان

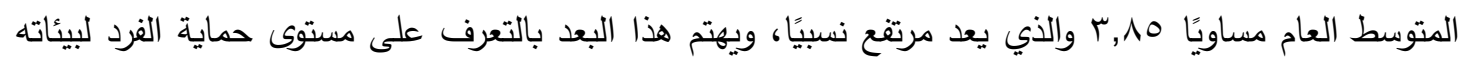

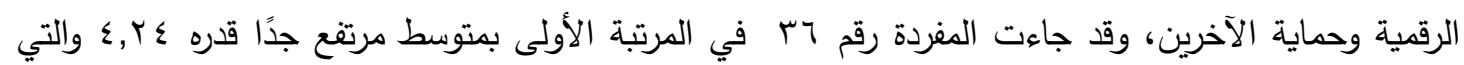

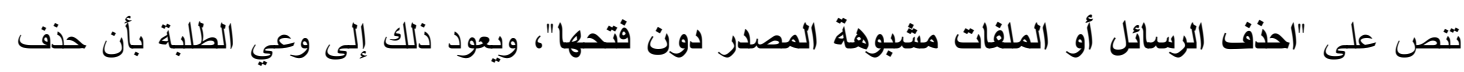

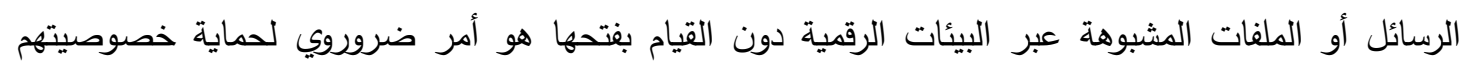

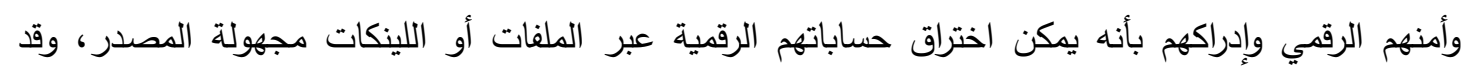

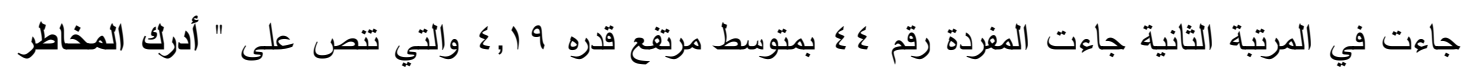

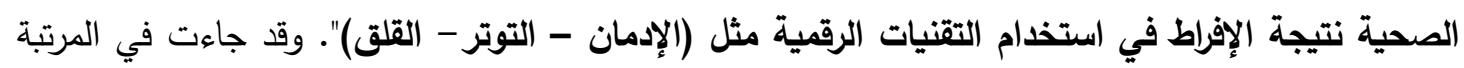

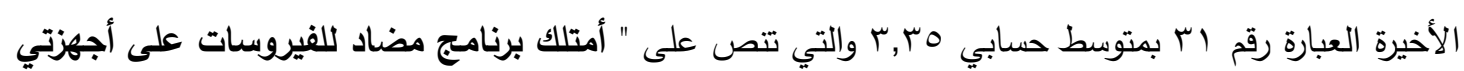
الأكترونية وأحدثها باستمرار" ويرجع ذلك لعدم توافر الإدراك الكامل لدى عينة الداستة بأهمية امتلاك برنامج

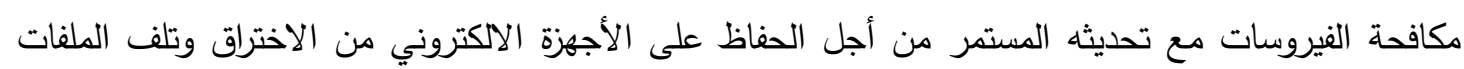

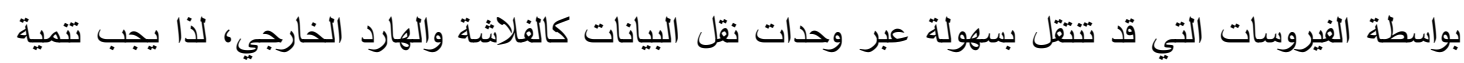
وعي الطلاب بأهمية الحماية الرقمية تجنبًا لاختراق أجهزتهم وللحفاظ على خصوصيت وحيتهم وملفاتهم من السرقة،

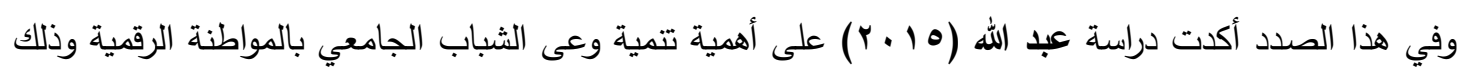
من خلال التدخل المهني باستخدام الممارسة العامة للخدمة الاجتماعية، وتوصلت إلى فعالية برنامج التدخل

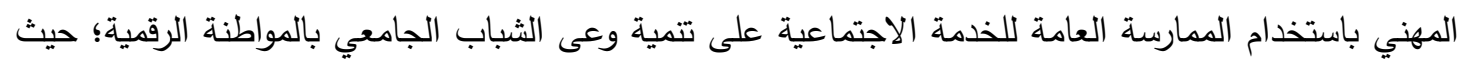
وجد وجود فروق ذات دلالة إحصائية بين القياس القبلي والقياس البعدي بالنسبة لدقياس المواطنة الرقمية لكلا

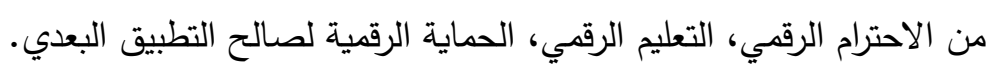

r) تحليل نتائج الدارة وفقاً للتساؤل الثاني: والذي ينص على "ما مدى اختلاف مستوى المواطنة الرقمية

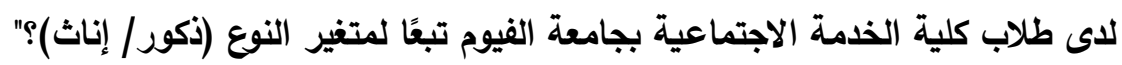
وللتعرف على مدى اختلاف مستوى المواطنة الرقمية وفقا لمتغير النوع، استخدم اختبار ت للعينات المستقلة T Independent Sample T-Test جدول (· ( ) نتائج اختبار T للعينات المستقلة

\begin{tabular}{|c|c|c|c|c|c|c|}
\hline \multirow{2}{*}{ الدلالة } & \multirow{2}{*}{ قيمة T } & \multirow{2}{*}{ فروقط } & \multicolumn{2}{|c|}{ المتوسط } & \multirow{2}{*}{ ليفين اختبار } & \multirow{2}{*}{ المتغير } \\
\hline & & & إناث & ذكور & & \\
\hline$\cdot, \cdot \leqslant V$ & $\bar{r}$ & $r, 1$ & $\{0,1$ & $\varepsilon r$ & $\cdot, \pi V$ & الاحتر ام \\
\hline$\cdot, \cdot Y V$ & Y,YO & $\varepsilon, r$ & $7 r, 1$ & $77, \varepsilon$ & $* \xi, \wedge 1$ & التعليم \\
\hline$\cdot, 77$ & $\cdot, \varepsilon r$ & $\cdot, 7$ & or,$\lambda$ & $0 \leqslant, \varepsilon$ & $*_{0,1 V}$ & الحماية \\
\hline • & $\cdot, 19$ & $r, V$ & $|7|, 1$ & $17 \pi, \lambda$ & $* \varepsilon, \cdot V$ & المو اطنة الرقمية \\
\hline
\end{tabular}

*دالة إحصائية عند مستوى 0 ., •

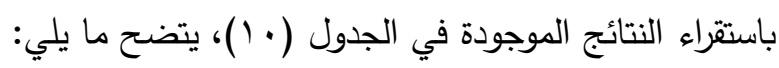
- تحقق شرط تجانس التباين، وأنه توجد فروق دالة إحصائية عند مستوى دلالة ه. . . • في محور الاحترام تعزي لمتغير النوع لصالح الإناث. وجود فروق دالة إحصائية عند مستوى دلالة ه ه. ,. في محور التعليم تعزي لمتغير النوع لصالح الذكور، على الرغم من عدم تحقق شرط تجانس التباين. 
- لا توجد فروق دالة إحصائية عند مستوى ه.,. • في محور الحماية أو المواطنة الرقمية ككل تعزي لمتغير

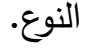

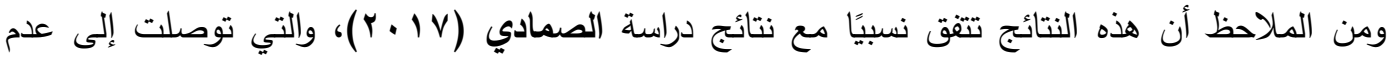
وجود فروق ذات دلالة إحصائية في المواطنة الرقمية تبعاً لمتغير النوع. ع) عرض نتائج الدراسة الحالية وفقاً للتساؤل الثالث: والذي ينص على "ما مستوى الوعي الفكري لاى طلاب كلية الخدمة الاجتماعية بجامعة الفيوم؟" جدول (11) متوسط درجات استجابت طلاب كلية الخدمة الاجتماعية حول " الوعي الفكري"

\begin{tabular}{|c|c|c|c|c|}
\hline | درجة الوعي & الرتبة & | الاتحراف & المتوسط & 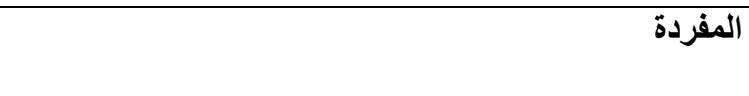 \\
\hline | مرتفعة جدًا & r & $\cdot, 7 \Lambda$ & $\varepsilon, \varepsilon 9$ & ا ـ أهتم بالحفاظ على هويني الثقافية. \\
\hline | مرتفعة جدًا & 0 & $\cdot, \mathrm{V} 7$ & $\varepsilon, \varepsilon \varepsilon$ & r. أهتم بالحفاظ على هويتى الوطنيه. \\
\hline | مرتفعة جدًا & 1 & $\cdot, \mathrm{TV}$ & $\varepsilon, 09$ & r. أحترم أراء الآخرين بغض النظر عن دينهم أو عرقهم. \\
\hline | مرتفعة جدًا & $\Lambda$ & $\cdot, 91$ & $\varepsilon, \pi$ & ع. أرفض الأفكار المنحرفة لدى الافر اد بالأدلة العلمية. \\
\hline | مرتفعة جدًا & 17 & $\cdot, 10$ & $\varepsilon, Y$. & مـ أقوم بمعرفة ما يجري حولي في العالم من أحداث. \\
\hline | مرتفعة جدًا & 9 & $\cdot, \Lambda \mathrm{T}$ & $\varepsilon, \pi$ & 7. أتحقق من المعلومات التي اسمعها قبل قبولها. \\
\hline | مرتفعة & IV & $\cdot, \mathrm{AT}$ & $\varepsilon, 10$ & V. أمتلك القدرة على النقل بموضو عية لآر اء الأخرين. \\
\hline |مرتفعة & T. & $\cdot, 91$ & $\varepsilon, \cdot V$ & 1. أشنارك في الاعمال التطو عية وخدمة المجتمع. \\
\hline | مرتفعة جدًا & $1 \varepsilon$ & $\cdot, A r$ & $\varepsilon, Y, T$ & 9 ـ. يزداد انتمائي الوطني بزيادة التحديات التي تواجهه. \\
\hline | مرتفعة & YI & $\cdot, 9 \wedge$ & $\varepsilon, .0$ & . أ. أَققبل النقد من الاخرين. \\
\hline | مرتفعة جدًا & 7 & $\cdot$, Vo & $\varepsilon, \varepsilon \cdot$ & الحوار. أحرص على الاستماع الجيد لحديث الاخرين أثناء \\
\hline | مرتفعة جدًا & $\varepsilon$ & $\cdot, \mathrm{Vq}$ & $\varepsilon, \leqslant 0$ & r ا ـ. أؤمن بحرية التعبير عن الر أي لكل الأفراد. \\
\hline 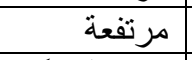 & 11 & $\cdot, 90$ & $\varepsilon, 1 \leq$ & r ا ـ قبول الاختلاف في الرأي مهم لنبذ التعصب. \\
\hline | مرتفعة جدًا & 14 & $\cdot, \mathrm{V} \wedge$ & $\varepsilon, Y \leqslant$ & ـ ـ ـ أؤمن بالفكر الوسطي و المعتدل. \\
\hline 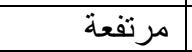 & rY & $1, \cdot \varepsilon$ & $r, 99$ & 10 ـ يمكنني التسامح بعد اعتذار أفر اد ظلموني من قبل. \\
\hline | مرتفعة جدًا & $\mathrm{r}$ & $\cdot, 1 / 9$ & $\varepsilon, \varepsilon q$ & 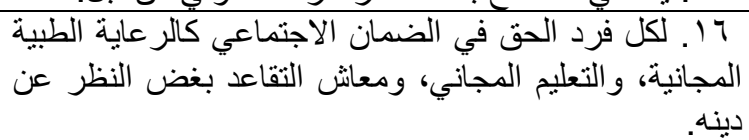 \\
\hline | مرتفعة جدًا & $1 \cdot$ & $\cdot, 10$ & $\varepsilon, \pi$ & V I ل لكل فرد الحرية في امتلاك وبيع الممتلكات. \\
\hline | مرتفعة جدًا & ir & $\cdot, 10$ & $\varepsilon, Y V$ & 1^ا أحسن الظن أثناء التعامل مع الاخرين. \\
\hline | مرتفعة جدًا & $\mathrm{V}$ & $\cdot, \mathrm{V} 9$ & $\varepsilon, \Gamma \Lambda$ & جنسه. أتعامل مع أي فرد بموضوعية مهما كان دينه، عرقه، \\
\hline | مرتفعة & $r T$ & $\cdot, 99$ & $r, 9 \wedge$ & 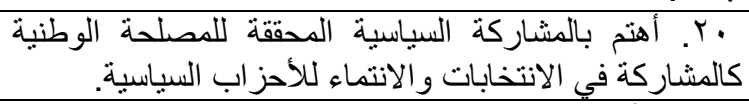 \\
\hline مرتفعة & 19 & $1, .7$ & $\varepsilon, 1 Y$ & ا Y. لا أؤمن بالعنصرية. \\
\hline | مرتفعة جدًا & 10 & $\cdot, \wedge \varepsilon$ & $\varepsilon, Y$ & اللجوء للعنف. أحل مشكلاتي بالحوار والطرق القانونية ولا يمكنني \\
\hline | مرتفعة جدًا & 11 & $\cdot, 94$ & $\varepsilon, r T$ & بr r. لا أقوم بنشر المعلومات و الاخبار التي أثنك بصحتها. \\
\hline | مرنفعة جدًا & & $\cdot, \wedge 0$ & $\varepsilon, Y q$ & متو سط درجات البعد \\
\hline
\end{tabular}

وفقًا لمتوسط درجات استجابات الطلاب حول الوعي الفكري الموجودة في جدول (1)(1)، يمكن القول بأن

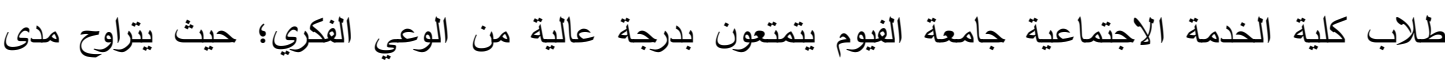

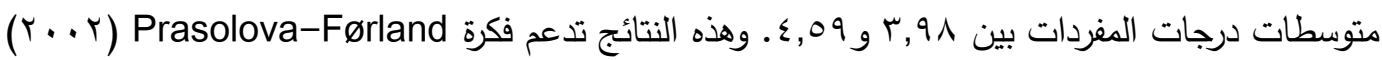
والذي أكد على أن الطلبة لديها رغبة قوية في أن يكونوا أكثر وعيا وإدراكا لدكونات الوعي.

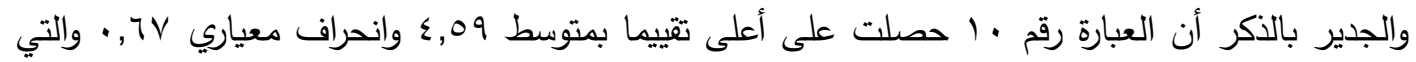
تتص على " أحترم آراء الآخرين بغض النظر عن دينهم أو عرقهم."، ، ويليها في الترتيب كأعلى متوسطا تأتي 
العبارتين رقم ا" أهتم بالحفاظ على هويتي الثقافية."، والعبارة رقم 17 "لكل فرد الحق في الضمان

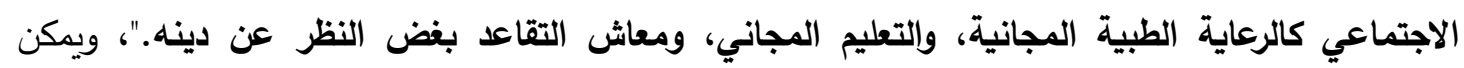

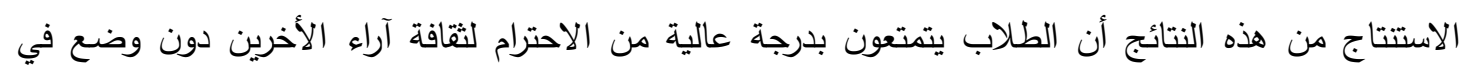

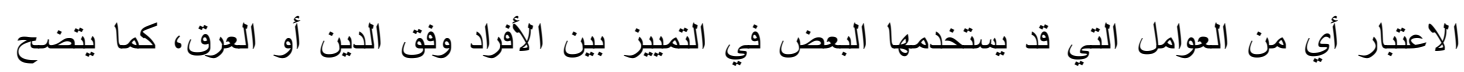
اهتمامهم الثديد بحفاظهم على هويتهم الثقافية وتقديرهم الثديد لحق الفرد في الضمان الاجتماعي كالرعاية

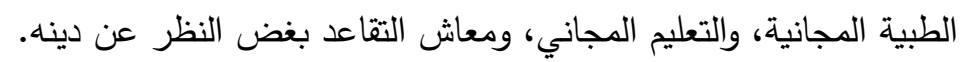

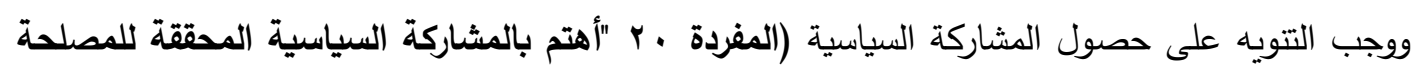

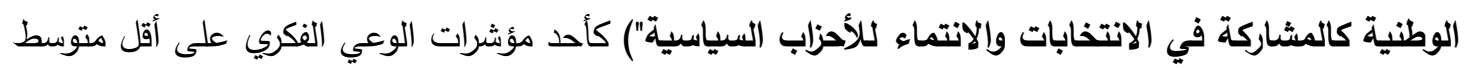

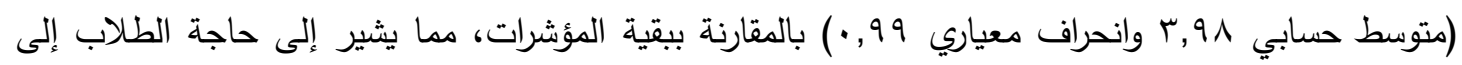
إعداد برامج توعية من منظور الخدمة الاجتماعية والتي قد تساعدهم على معرفة أهمية المشاركة السياسية

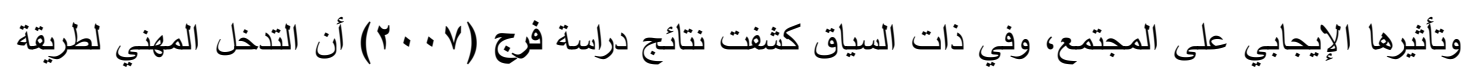

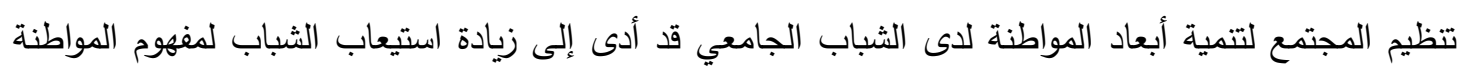
وأيضا زيادة مستوى ممارسة حقوق وواجبات المواطنة وتتمية المشاركة السياسية والمسئولية الاجتماعية لدى الدئي

•) تحليل نتائج الدراسة وفقاً للتساؤل الرابع: والذي ينص على "ما مدى اختلاف مستوى الوعي الفكري

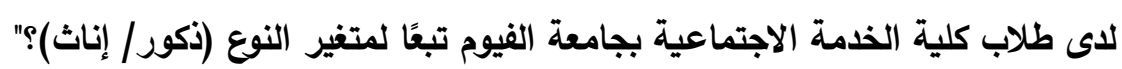

وللتعرف على مدى اختلاف مستوى الوعي الفكري وفقا لمتغير النوع، تم استخدم اختبار ت للعينات المستقلة T Independent Sample T-Test

\begin{tabular}{|c|c|c|c|c|c|c|}
\hline الدلالة & قيمة T T T & \multicolumn{2}{|c|}{ اختبار ليفين للتجانس } & \multirow{2}{*}{ فروق المتوسط } & \multirow{2}{*}{ المتوسط } & \multirow{2}{*}{ المتغير } \\
\hline \multirow{3}{*}{$\cdot, 071$} & \multirow{3}{*}{$\cdot, 0 \wedge r$} & الدلالة الد & $\mathrm{F}$ & & & \\
\hline & & \multirow{2}{*}{ • } & \multirow{2}{*}{$r, r q$} & \multirow{2}{*}{ r } & $9 \vee, 1$ & ذكور \\
\hline & & & & & $9 \wedge, \varepsilon$ & إناث \\
\hline
\end{tabular}

"دالة إحصائية عند مستوى 0 .,.

باستقراء النتائج الموجودة في الجدول (Y) ()، يتضح تحقق شرط تجانس التباين، وأنه لا توجد فروق دالة

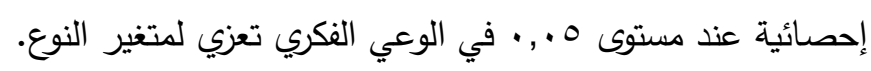

7) عرض نتائج الدراسة الحالية وفقاً للتساؤل الخامس، والذي ينص على "ما العلاقة بين المواطنة الرقمية والوعي الفكري لدى طلاب كلية الخدمة الاجتماعية بجامعة الفيوم؟

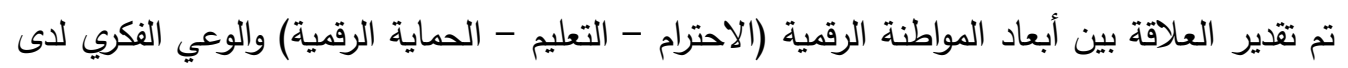

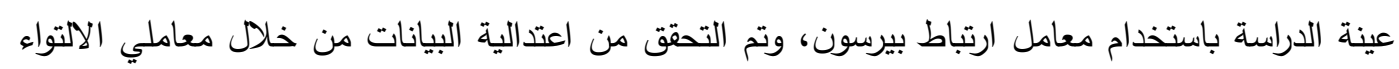

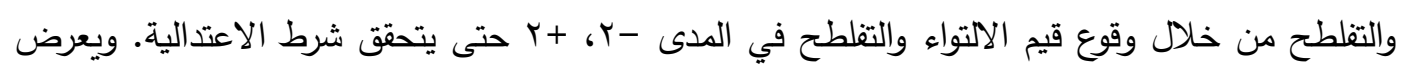
جدول (r ا) نتائج الالتواء والتفلطح والمتوسط الحسابي والانحراف المعياري لمتغيرات الدراسة. 


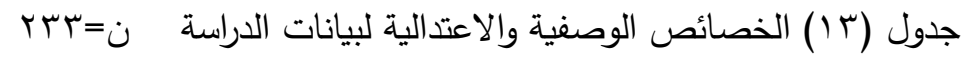

\begin{tabular}{|c|c|c|c|c|c|}
\hline \multicolumn{2}{|c|}{ اعتدالية البيانات } & الانحر اف & \multirow{2}{*}{ المتوسط } & & \\
\hline التفلطح & الالتو اء & المعياري & & & \\
\hline $1,0$. & $1, q_{-}$ & $T, Y Y$ & $\varepsilon \varepsilon, \vee 0$ & الاحتر ام & \multirow{4}{*}{ 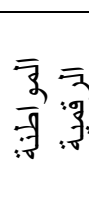 } \\
\hline$\cdot$, ro & $\cdot, 7 \cdot-$ & $1 T, O V$ & $7 r, \wedge 9$ & التعليم & \\
\hline$\cdot, r q$ & $\cdot, 0 \leqslant-$ & $9, r \leqslant$ & or,qr & الحماية الرقمية & \\
\hline$\cdot, \cdot 1$ & • & $r 1, Y \wedge$ & 171,09 & الدرجة الكلية & \\
\hline $1, \mu_{0}$ & $1, r{ }_{-}$ & Ir, ro & $9 \Lambda, Y)$ & ي الفكري & \\
\hline
\end{tabular}

يتضح من نتائج جدول (r ( ) أن هناك توزيع اعتدالي للبيانات للأبعاد الفرعية لمقياس المواطنة الرقمية، وأيضا

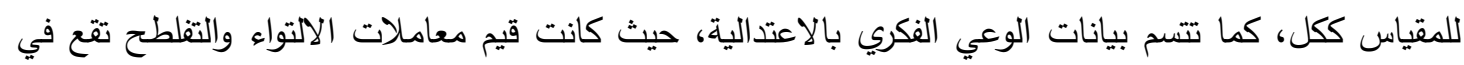
المدى المتعارف عليه من قبل الباحثين. ويستعرض الجدول (ع () نتائج الارتباط بين مقياس المواطنة الرقمية بأبعادة الثلاثة ومقياس الوعي الفكري، كما يعرض شكل (广) مصفوفة مخططات الانتثار لمتغيرات الدراسة.

\begin{tabular}{|c|c|}
\hline الوعي الفكري & المواطنة الرقمية \\
\hline$* * ., \leqslant 7 V$ & الاحتر ام \\
\hline${ }^{* *},, Y \ldots$ & التعليم \\
\hline **., T.V & الحماية الرقمية \\
\hline **., OYA & الدرجة الكلية \\
\hline
\end{tabular}

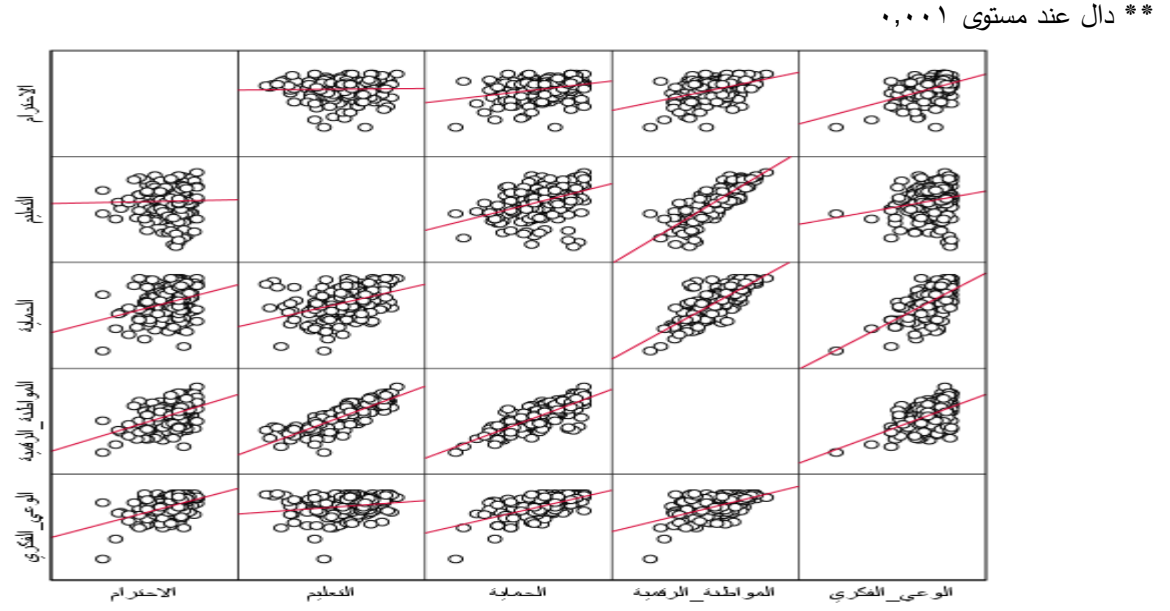

شكل (r) مصفوفة مخططات الانتثار scatter plot لوصف العلاقة بين متغيرات الدراسة

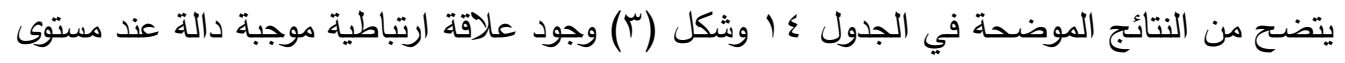

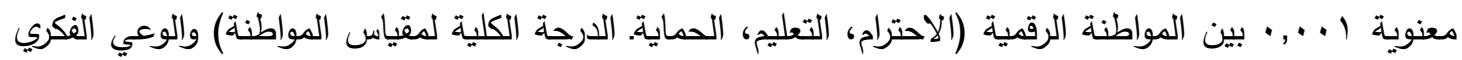

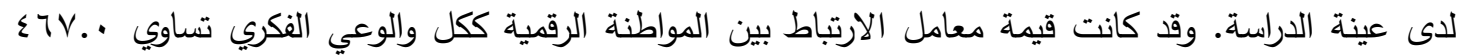
بدلالة إحصائية عن مستوى | +.,.، وهذا يشير إلى وجود علاقة ارتباطية طردية موجبة متوسطة بينهما. ومن

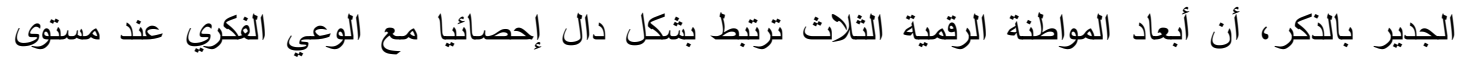

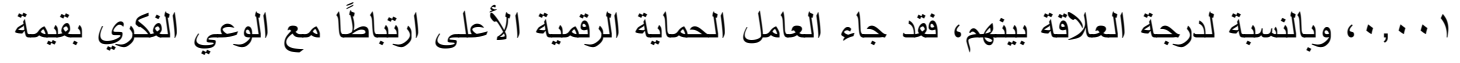

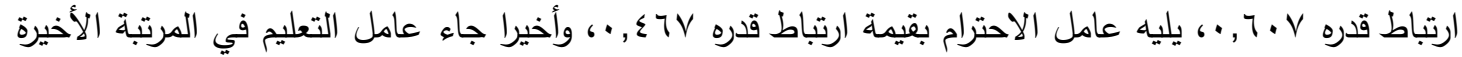
من حيث درجة الارتباط بالوعي الفكري بارتباط قدره • r, •. 
كما يتضح من شكل (r) أيضا أنه توجد علاقة خطية بين جميع متغيرات الدراسة، حيث يشير الخط المرسوم بين متغيرات الدراسة إلى وجود علاقة طردية موجبة.

V تحليل نتائج الاراسة وفقاً للتساؤل السادس: والذي ينص على "مات القدرة التنبؤية لأبعاد المواطنة الرقمية

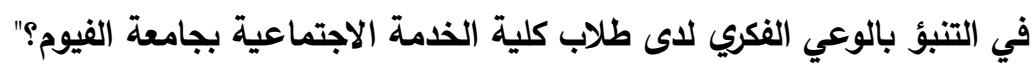

استخدم تحليل الانحدار بطريقة Enter للإجابة على هذا التساؤل، وتم التحقق من افتراض خطية العلاقة

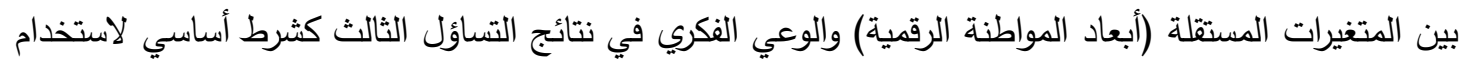

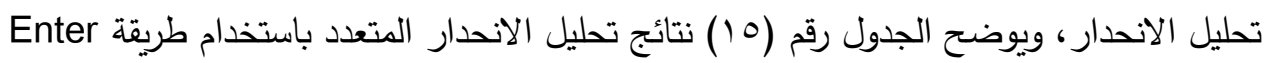
جدول (0) نتائج تحليل التباين ANOVA بين المتغيرات المستقلة (الاحترام، التعليم، الحماية) والوعي الفكري

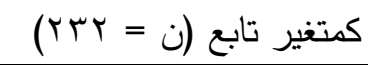

\begin{tabular}{|c|c|c|c|c|c|c|c|c|}
\hline 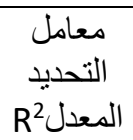 & $\begin{array}{c}\text { التحديد } \\
\text { Rعامل } \\
\text { R2 }\end{array}$ & $\mathrm{R}$ & الدلالة & $\mathrm{F}$ & المربعات & الحرجية & المربعاتع & \\
\hline \multirow{3}{*}{ - $\leqslant$. } & \multirow{3}{*}{ -,$\leqslant 0 \mathrm{~V}$} & \multirow{3}{*}{. } & \multirow{3}{*}{$\cdot, \ldots$} & \multirow{3}{*}{$T \leqslant, T_{0}$} & OrqY,O & $r$ & $17 / V V, T$ & الانحدار \\
\hline & & & & & $\wedge r, \vee q$ & FYq & $191 \wedge 9,7$ & البو اقى \\
\hline & & & & & & TMY & rorty, Y & الكلي \\
\hline
\end{tabular}

جدول (7 (1) قيم معاملات الانحدار بين المتغيرات المستقلة (الاحترام، التعليم، الحماية كمتغير متتبئ)

$$
\text { والوعي الفكري (متغير تابع) }
$$

\begin{tabular}{|c|c|c|c|c|c|}
\hline \multirow{2}{*}{ مستوى الدلالة } & \multirow{2}{*}{ قيمة t } & \multirow{2}{*}{ معامل الانحدار } & \multicolumn{2}{|c|}{ معامل الانحدار غير المعيارية } & \\
\hline & & & الخطأ المعياري & B & \\
\hline$\cdot, \ldots$ & $7,0 \mathrm{~V}$ & & $0, Y V$ & $r \varepsilon, \tau$ & الثنابت \\
\hline$\cdot, \cdots$ & $0,9 \mathrm{~V}$ & $\cdot, r \cdot \Lambda$ & $\cdot, 1 \cdot r$ & $\cdot, 7)$ & الاحتر ام \\
\hline$\cdot, 09 \mathrm{~V}$ & $\cdot, 0 Y 9$ & $\cdot, \cdot 9_{-}$ & $\cdot, \cdot \leqslant 9$ & $\cdot, \cdot$ YY_ & 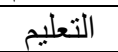 \\
\hline$\cdot, \ldots$ & $9, Y 71$ & $\cdot, 0 Y 7$ & $\cdot, .87$ & $\cdot, V \cdot Y$ & الحماية \\
\hline
\end{tabular}

باستقراء النتائج الموجودة في الجدولين 17، V V V، نجد أن نموذج تحليل الانحدار الحالي يمتلك دلالة إحصائية بين المتغيرات المستقلة (الاحترام، التعليم، الحماية كمتغير متتبئ) والوعي الفكري كمتغير تابع، حيث كانت قيم

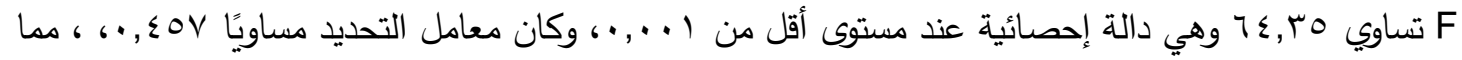

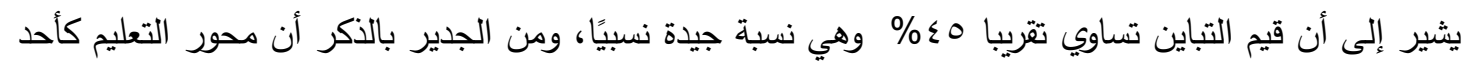
عوامل المواطنة الرقمية كان غير دالة إحصائيًا مما يدل على عدم امتلاكها قدرة تتبؤية بالوعي الفكري لطلاب الجامعة، أما قيم الانحدار غير المعيارية والمعيارية لمحوري الاحترام والحماية كانت دالة عند مستوى الـ ل.,. للتتبؤ بالوعي الفكري وبالتالي يمكن كتابة معادلة الانحدار كالتالي: معادلة الانحدار غير المعيارية:

الوعي الفكري =

$$
\text { معادلة الانحدار المعيارية: }
$$

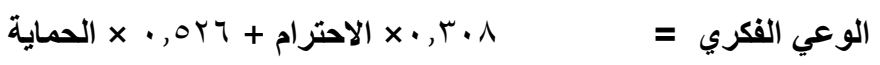

وفي هذا السياق أظهرت نتائج دراسة (2010) . Choochom et al إلى أن العوامل النفسية والاجتماعية

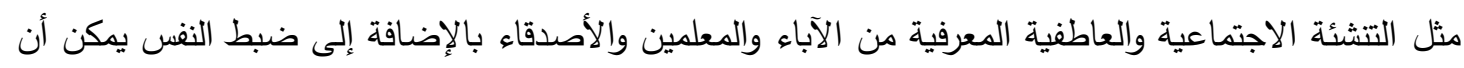
تتنبأ بالوعي الفكري للطلاب والذي بدوره كان له تأثير على السلوك الاجتماعي الإيجابي للطلاب وحل

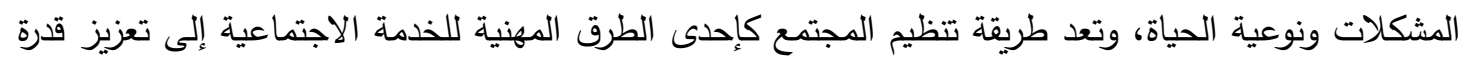


المجتمع على استغلال طاقات وجهود الأفراد من خلال تتمية قدراتهم على التفكير والإبداع والتحليل وتستهدف أيضا رفع

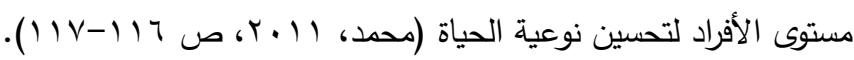

ثامنًا: تضمينات الاراسة من منظور طريقة تنظيم المجتمع:

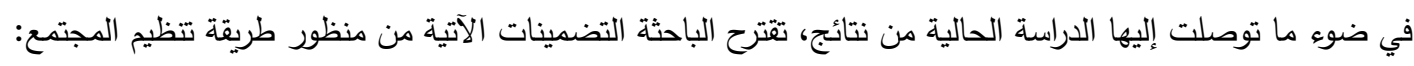
1- توعية الثباب الجامعي وتوجيهم نحو الممارسات الآمنة والقانونية والأخلاقية، وحماية حقوق الملكية الفكرية.

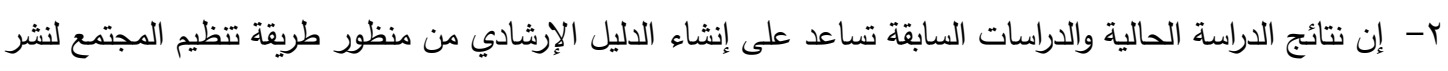
ثثافة المواطنة الرقمية لدى الثباب الجامعي.

r- الاعتماد على رؤية مصر •r.r في تعزيز العالم الرقمي والهوية الوطنية لاى الثباب الجامعي.

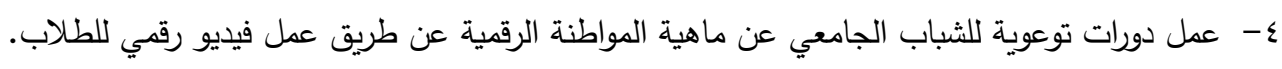

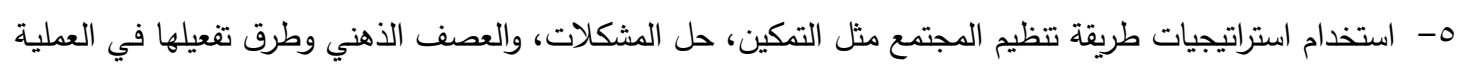

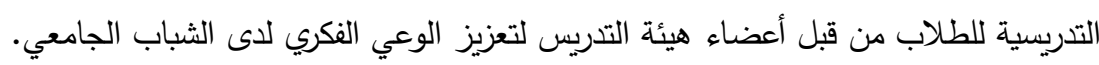

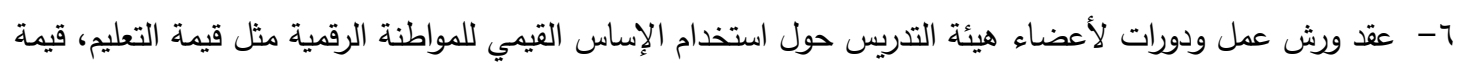
الاحترام والقيم المتعلقة بالأمان من أجل تعزيز الوعي بحقوق الملكية الفكرية.

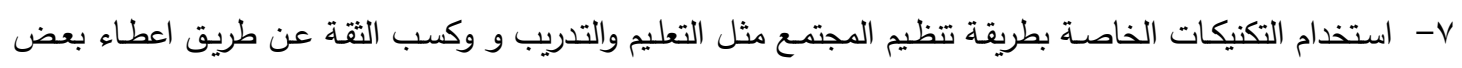

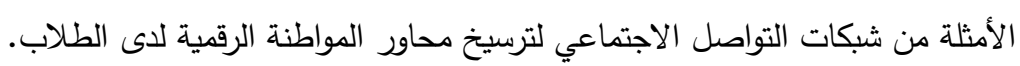

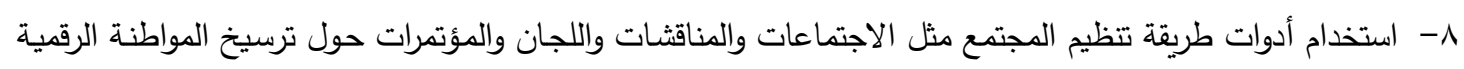

$$
\text { للثباب الجامعي. }
$$

9- استخدام استراتيجيات تنظيم المجتمع لنشر المواطنة الرقمية للثباب الجامعي وحثهم على المشاركة الإيجابية لتعزيز

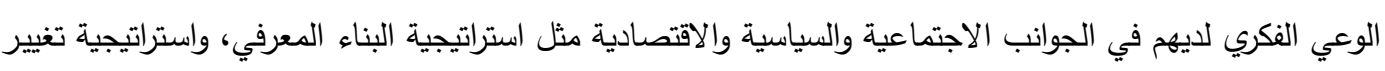
السلوك.

• 1- استخدام المهارات اللازمـة لتعزيز الوعي الفكري للى الثباب الجامعي مثل الاتصـال والعمل الفريقى والتسجيل باستخدام الوسائل التكنولوجية.

1ا- استخدام الأدوار المهنية اللازمة لتعزيز المواطنة الرقمية لدى الثباب الجامعي مثل المرشد المكن والمخطط القائد المهني والتزبوي والخبير عن طريق عقد دورات تدريبية لمحو الآمية الرقمية.

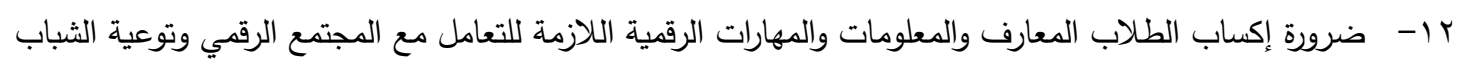

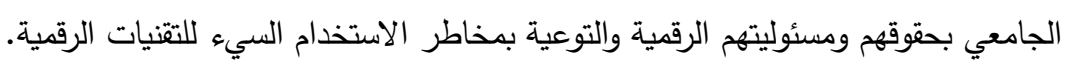

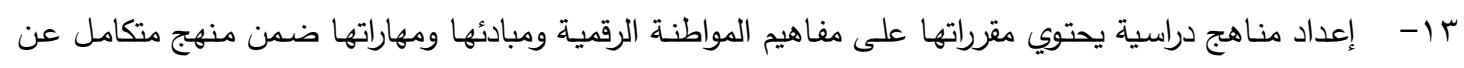
العالم الرقمي.

\section{تاسعًا: مقترحات لاراسات مستقبلية:}

في ضوء نتائج الدراسة الحالية، يمكن إجراء العديد من الدراسات المستتقلية الآتية:

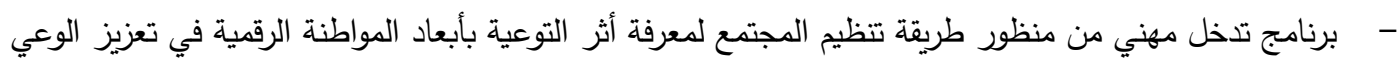
الفكري ومواجهة التطرف الفكري لاى الثباب الجامعي.

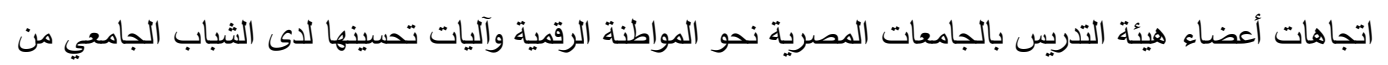
منظور الخدمة الاجتماعية. 
قائمة المراجع:

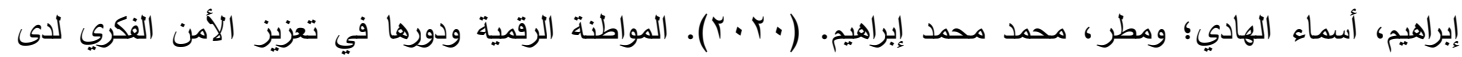

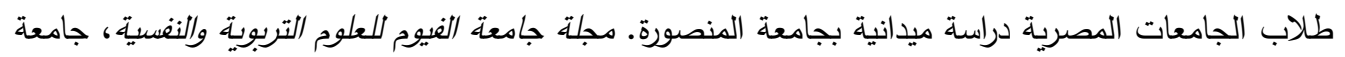

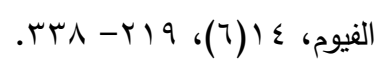

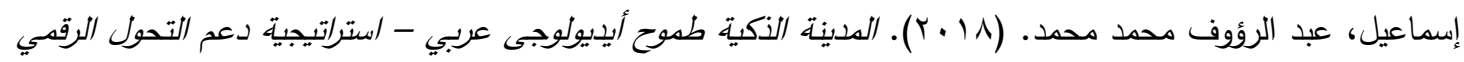

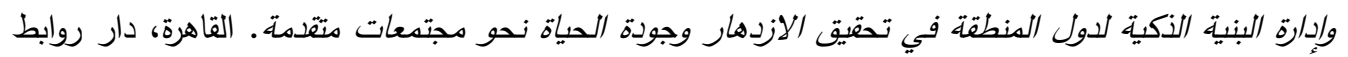
للنشر وتقنية المعلومات.

البلوى، حنان على مسلم؛ وسليمان، شاهر خالد. (9 ( ب). بناء مقياس الوعي الفكري باستخدام التحليل العاملي التوكيدي"

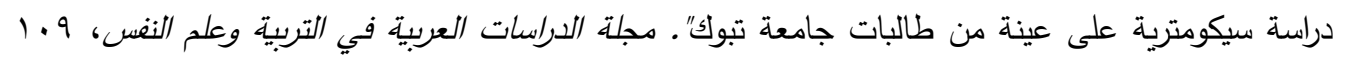

$.91-V 1$.

الخالدي، ملاك محمد اللحيد. (1) • ب). الوعي الفكري والانسلاخ الثقافي. مركز عبد الرحمن السديري الثقافي.

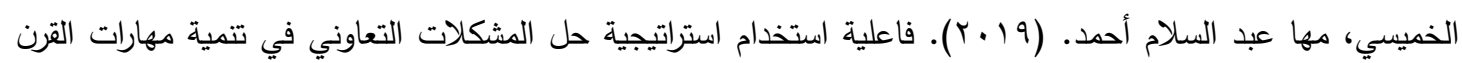

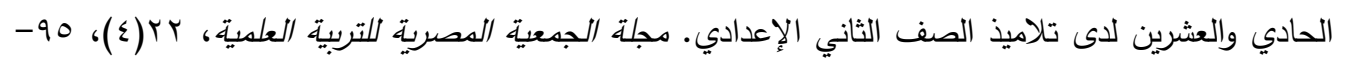

\section{$.1 \%$}

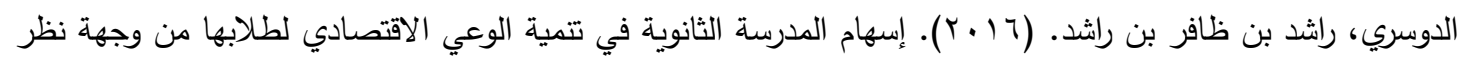

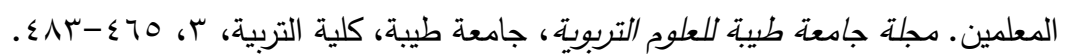

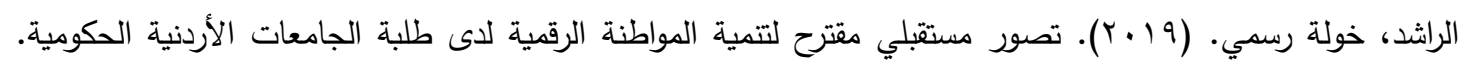

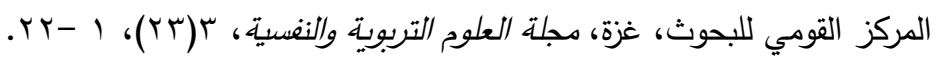

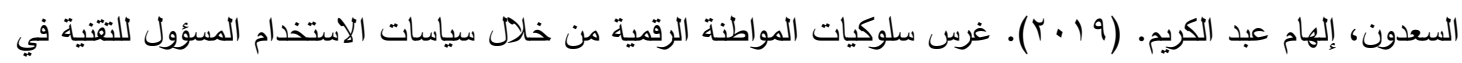

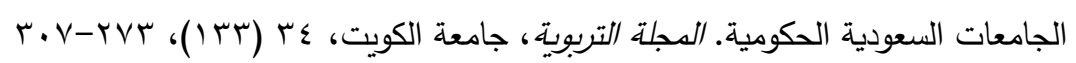

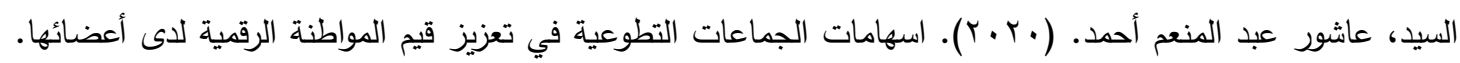

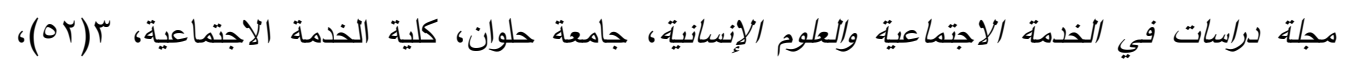

$$
\text { .717-0V9 }
$$

السيد، محمد عبد البديع. (r 17 •). دور وسائل الإعلام الجديدة في دعم المواطنة الرقمية لدى طلاب الجامعة. مجلة

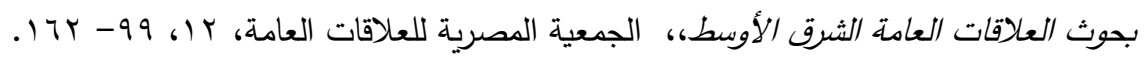

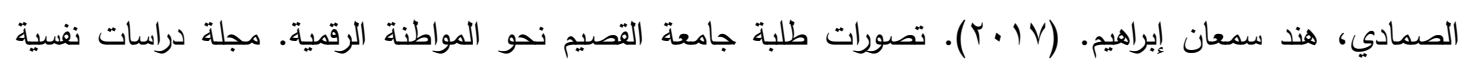

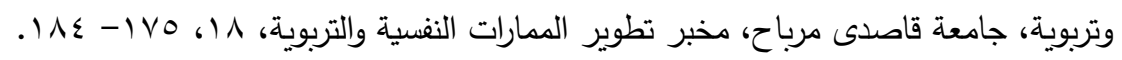

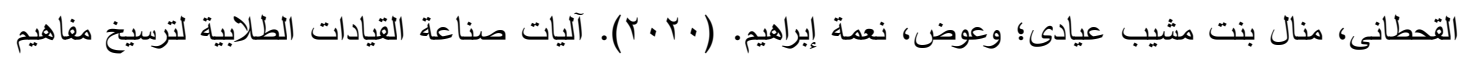

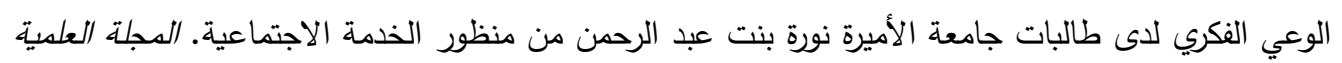

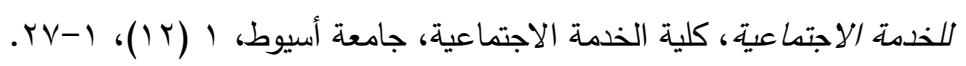

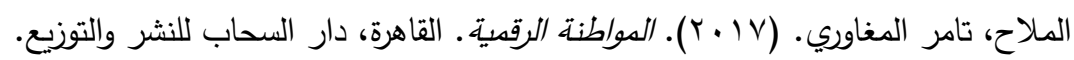

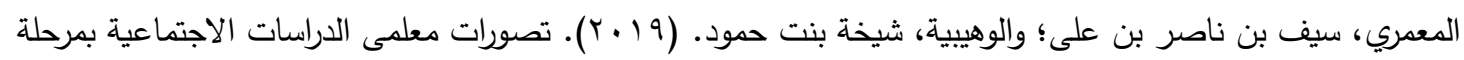
التعليم ما بعد الأساسي في سلطنة عمان عن المواطنة الرقمية. مجلة العلوم التربوية، كلية الدراسات العليا

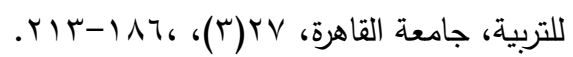

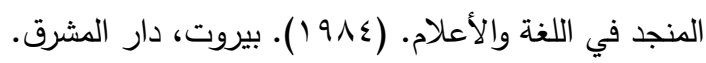




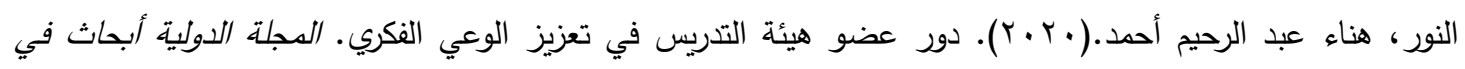

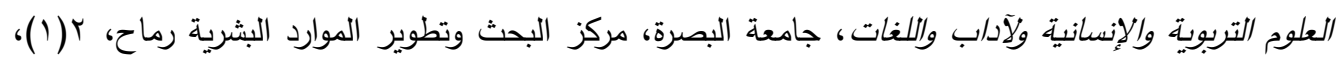

$.04 \mathrm{~V}-011$

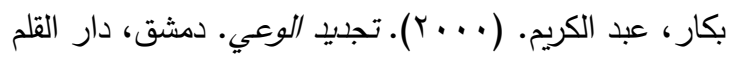

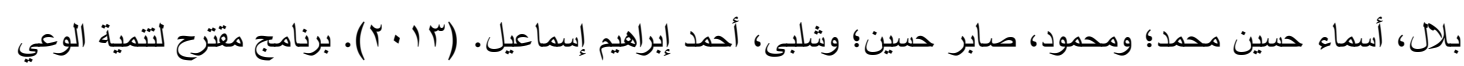

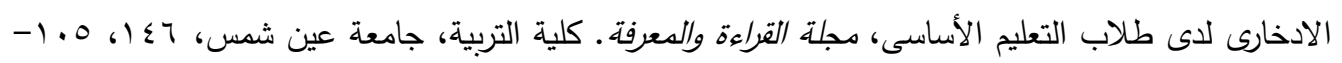

\section{. IY}

حسانين، سيد أبو بكر • (9V7 (1). طريقة الخدمة الاجتماعية في تنظيم المجتمع. القاهرة، مكتبة الأنجلو المصرية.

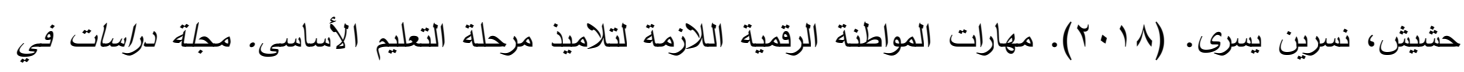

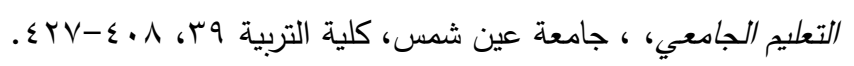

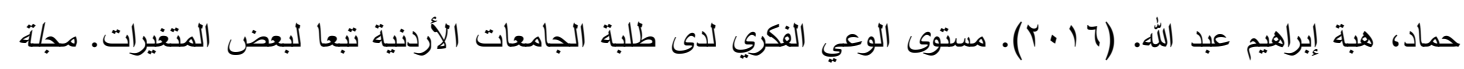

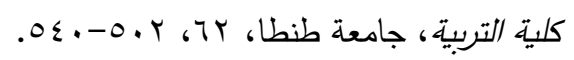

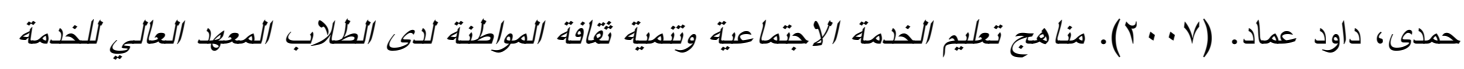

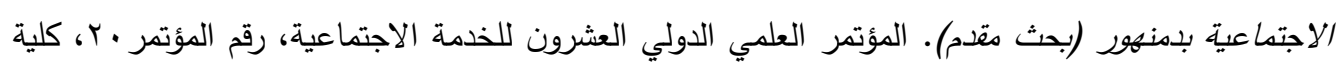

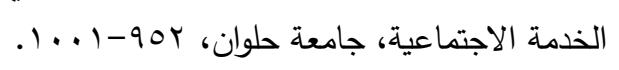

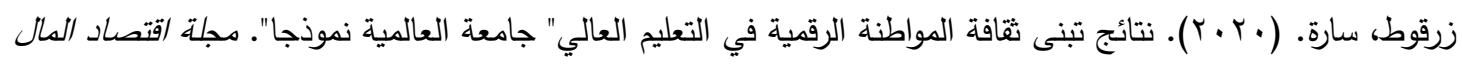

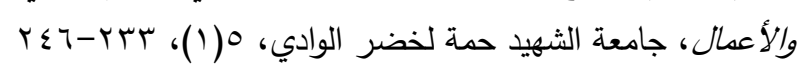

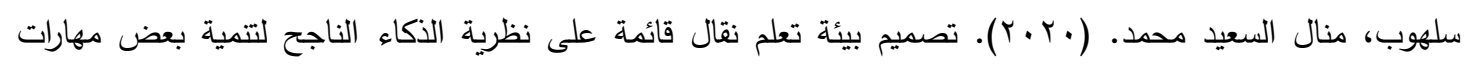

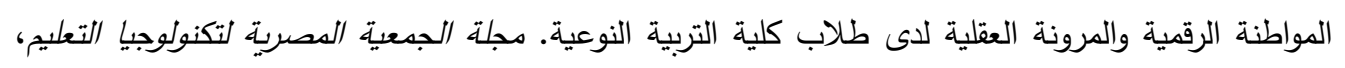

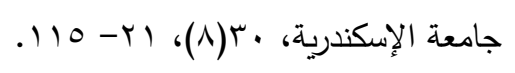

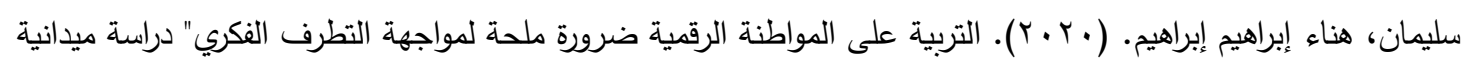

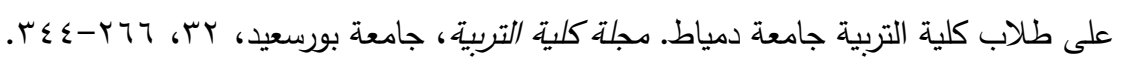

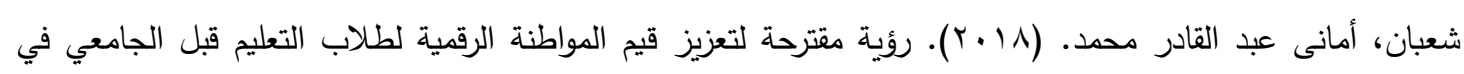

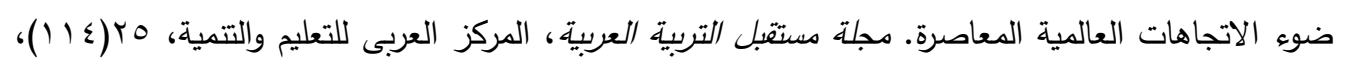

$$
\text { . Irtr-Vr }
$$

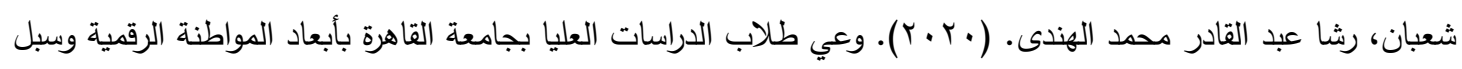

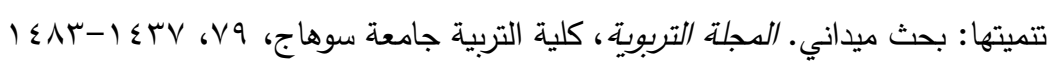

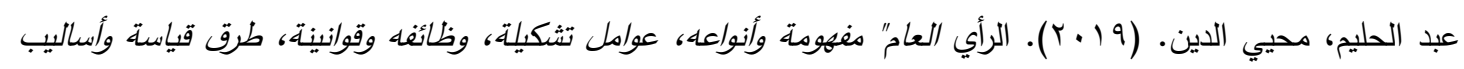

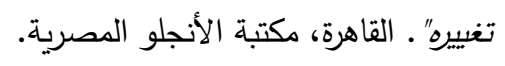

عبد الله، حمدي عبد الله عبد العال. (10 • ب). الممارسة العامة للخدمة الاجتماعية وتتمية وعى الثباب الجامعي بالمواطنة

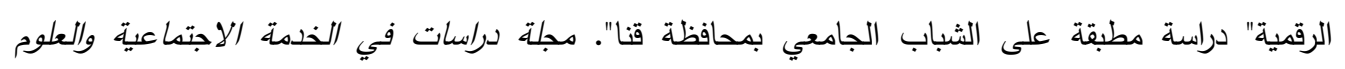

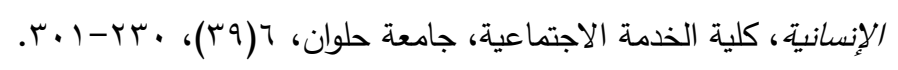

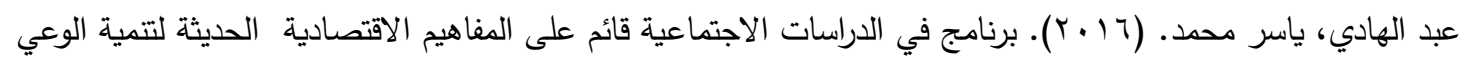

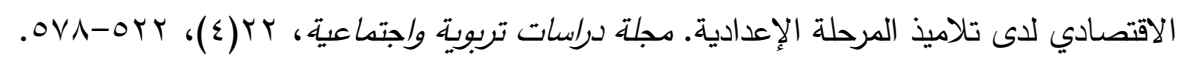

عليمات، عبير راشد. (9 (ب). دور مواقع التواصل الاجتماعي في تحقيق الوعي الفكري الوطني ومعالجة القضايا

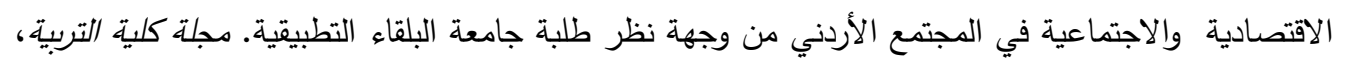

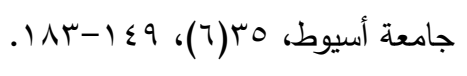




$$
\begin{aligned}
& \text { عنانزة، مها محمد أحمد؛ والقاعود، إبراهيم عبد القادر أحمد. (9 ( • (Y). مدى وعى طلبة جامعة اليرموك بمخاطر الإرهاب }
\end{aligned}
$$

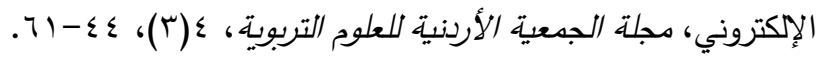

$$
\begin{aligned}
& \text { فاضل، صدقة يحيى. (9 ( ا (Y). الوعي السياسي" أهمية وطريقة عامة مقترحة لقياسة. مجلة الدراسات الدولية، وزارة }
\end{aligned}
$$

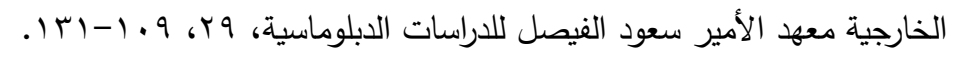

$$
\begin{aligned}
& \text { فرج، سامية بارح. (V . . r). التدخل المهني لطريقة تنظيم المجتمع لتندية قيم المواطنة لدى الثباب (بحث مقدم). المؤتمر } \\
& \text { الدولي التاسع عشر ، كلية الخدمة الاجتماعية، جامعة حلوان. } \\
& \text { محافظة، سامح محمد. (1) (1). دور الجامعة الهاشمية في خدمة المجتمع المحلي من وجهة نظر أعضاء هيئة التدريس } \\
& \text { فيها (بحث مقدم). المؤتمر العلمي الرابع لكلية العلوم التربوية بجامعة جرش بعنوان" التربية والمجتمع: الحاضر }
\end{aligned}
$$

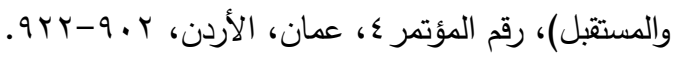

$$
\begin{aligned}
& \text { محمد، محمد عبد الفتاح. (11 (ب). الاتجاهات النظرية المعاصرة لتنظيم المجتمع"نماذج ونظريات - مهارات مهنية، } \\
& \text { الإسكندرية، المكتب الجامعي الحديث. }
\end{aligned}
$$

Al-Zahrani A (2015) Toward digital citizenship: Examining factors affecting participation and involvement in the Internet society among higher education students. International Education Studies 8(12): 203-217.

Bolkan, J. V. (2014): resources to help you to teach digital citizenship, T H E Journal, vol. 41 No. 12, p21-23.

Choochom, O., Sukharom, A., Intasuwan, P., \& Jinnge, P. (2010). Research and development of intellectual consciousness for Thai youths' quality of life. Procedia - Social and Behavioral Sciences, 5, 211-215. https://doi.org/10.1016/j.sbspro.2010.07.074

Dotter, G., Hedges, A., \& Parker, H. (2016). Fostering digital citizenship in the classroom. Education Digest,82(3), 58-63.

Molotova, V., Molotov, A., Kashirsky, D., \& Sabelnikova, N. (2020). Survey for Assessment of a Person's Legal Consciousness: Development and Preliminary Validation. Behavioral Sciences, 10(5), 89. https://doi.org/10.3390/bs10050089

Prasolova-Førland, E. (2002). Supporting awareness in education: Overview and mechanisms. In ICEE 2002.

Revelle, W. (2019). Using R and the psych package to find $\omega$. Evanston, IL, Northwestern University

Revelle, W. (2020). psych: Procedures for Psychological, Psychometric, and Personality Research (2.0.7) [Computer software]. https://CRAN.R-project.org/package=psych

Ribble, M., \& Bailey, G. (2007). Digital Citizenship in Schools. International Society for Technology in Education.

Ribble, M., \& Miller T.N. (2013). Educational leadership in an online world: Connecting students to technology responsibly, safely, and ethically. Journal of Asynchronous Learning Networks 17(1): 137-145. 